\title{
QUANDO SONHAR ESTÁ NA MODA - A NOSTALGIA DO FEMININO NA CULTURA DE CONSUMO
}

\author{
When dreaming is fashionable - the nostalgia of the \\ feminine in the consumption culture
}

\author{
Vânia Carneiro de Carvalho*
}

\begin{abstract}
RESUMO
Os repertórios materiais e visuais da aristocracia do século XVIII foram reapropriados pela sociedade moderna ocidental para criar clivagens entre os gêneros masculinos e femininos. Mas tais estratégias sociais não foram apenas de diferenciação. Na distinçãoo e hierarquização dos gêneros, criaram-se também novos territórios para o cultivo de subjetividades sexualizadas. Neste artigo o fenômeno está circunscrito à produção dos filmes de princesas de Walt Disney, especialmente Branca de Neve e os Sete Anões (1937) e Cinderela (1950). Pretendo demonstrar como a prática do devaneio romântico, conforme caracterizada por Colin Campbell, encontrou um terreno fértil no passado aristocrático do setecentos, reapresentado nostalgicamente como modelo de beleza e feminilidade na produção cinematográfica em questão ${ }^{1}$.
\end{abstract}

Palavras chave: Cultura material; Cultura visual; Cenas de Cortesia; Walt Disney; Nostalgia

\footnotetext{
ABSTRACT

The material and visual repertoires of the aristocracy of the eighteenth century were appropriated by modern Western society

* Docente no Museu Paulista da Universidade de São Paulo. vcarvalh@usp.br

1 Este artigo é parte de uma pesquisa mais ampla sobre cenas de cortesia e a constituição da feminilidade que até o momento recebeu apoios do Fundo de Pesquisa do Museu Paulista da USP, da FAPESP e do Institut nacional d'histoire de l'art (INHA/Fr).
} 
to create cleavages between masculine and feminine genders. But such social strategies were not just of differentiation. In the distinction and hierarchy of genders, new territories were also created for the cultivation of sexualized subjectivities. In this article the phenomenon is limited to the production of Walt Disney princess films, especially Snow White and the Seven Dwarfs (1937) and Cinderella (1950). I intend to demonstrate how the practice of romantic reverie, as characterized by Colin Campbell, found fertile grounds in the aristocratic past of the settecento, nostalgically restated as a model of beauty and femininity in the cinematographic production in question.

Keywords: Material Culture; Visual Culture; Courtesy scenes; Walt Disney; Longing

A partir de 2011, o Museu Paulista da USP iniciou a formação de uma coleção de objetos domésticos de serviço e decoração. O conjunto constituiu-se por pinturas, estampas, decalques e esculturas representando cenas de cortesia (scènes de courtoisie $)^{2}$. A coleta institucional de tais objetos praticamente se impôs frente à constatação, na pesquisa de campo que fazíamos ${ }^{3}$, de sua incidência recorrente no mercado local de antiguidades, procedência que nos garantia que tais artefatos foram usados em residências brasileiras, provavelmente da cidade de São Paulo e cidades (ou zonas rurais) circunvizinhas ${ }^{4}$. Referimo-nos mais especificamente a serviços de chá, xícaras de café (provavelmente oriundas de coleções privadas), pratos decorativos para parede ou mesa, ânforas, floreiras, vasos, centros de mesa, bibelôs, painéis têxteis e, especialmente, a esculturas de porcelana. A estes conjuntos decorativos somam-se outros objetos, de cunho pessoal e feminino, como porta-joias, broches, porta-batom,

2 Preferimos utilizar o termo cenas de cortesia (scènes de courtoisie) para abarcar os objetos que encontramos em circulação na cidade de São Paulo e que são inspirados nas pinturas e esculturas do século XVIII francês. No entanto, tais objetos representam cenas não somente associadas à natureza idealizada das fêtes galantes, mas também a objetos próprios da cidade ou do interior de residências aristocráticas.

3 A pesquisa deu-se no contexto do projeto de pesquisa e exposição Morar Paulistano, patrocinado pela Caixa Econômica Federal entre 2009 e 2013. A exposição não se concretizou por causa do fechamento do edifício-monumento do Museu em agosto de 2013. No entanto, as coletas para a pesquisa continuaram sendo realizadas até 2015 .

$4 \mathrm{O}$ mercado local de antiquariado - feiras e pequenas lojas - não importa objetos nem participa de leilões, sua fonte de renda consiste basicamente da coleta direta de objetos de usuários locais, feita através de contatos boca a boca e por captadores informais. 
pentes, frascos de perfume, caixa de pó compacto entre outros ${ }^{5}$. É preciso ainda acrescentar que, concebidas no século XVIII e, desde então, produzidas até os dias de hoje, as cenas de cortesia reunidas na coleção do Museu datam maciçamente da segunda metade do século XX. Entre exemplares de Meissen, Limoges e Capodimonte destacam-se os de produção brasileira como Renner, Rebis, Tasca, Vieiras de Castro e Santana ${ }^{6}$.

A partir dessas simples observações, duas perguntas, entre tantas possíveis, sobrelevam-se. É legítimo nos indagarmos o porquê de temáticas e personagens consumidos pela aristocracia e comerciantes ricos do século XVIII terem sido retomadas. E por que estes objetos se tornaram fortemente femininos, a ponto de serem adotados como ornamentos de uso pessoal. Quanto à última questão, se nos parece hoje evidente que os objetos de decoração doméstica foram, durante os séculos XIX e parte do XX, marca e missão da mulher, não está claro como passamos de um consumo de objetos afeitos a um alto estrato social e sem que houvesse distinções de gênero para um consumo intenso ou mesmo exclusivo associado ao gênero feminino. Neste longo processo é preciso ainda frisar que estes mesmos objetos, advindos de um repertório de luxo do setecentismo, transformam-se materialmente e morfologicamente, apesar de ainda serem identificáveis suas fontes originais de inspiração. Talvez, antes das duas questões acima, devamos justificar o investimento institucional em objetos deste tipo. Qual, afinal, a relevância social do consumo de cenas de cortesia configuradas em objetos de decoração? A resposta a esta questão não é simples, pois várias justificativas se sobrepõem. Trataremos de duas delas, que consideramos, para o presente objetivo, as mais relevantes.

A primeira delas diz respeito ao lugar primordial que o espaço doméstico ocupa na vida social quando a ele se funde a noção de interioridade psíquica. Tal dualidade, replicada pela difusão

5 Foram adquiridos pelo Museu 221 objetos decorativos representando cenas de cortesia.

6 CARVALHO, Vânia Carneiro de. Interior Objects Collection in a History Museum: Shifting from Donations to Research-Based Acquisitions. University Museums and Collections Journal, v. 7, p. 9-19, 2014. O artigo oferece uma ideia do tipo de trabalho de coleta que foi feito durante a pesquisa para o projeto Morar Paulistano, quando nos deparamos com os objetos decorativos com cenas de cortesia. http://umac.icom.museum/pdf/UMACJ-7.pdf 
maciça de imagens de interiores residenciais em meios de comunicação, tornaria o fenômeno mundialmente relevante ${ }^{7}$. O investimento psíquico nos objetos e espaço doméstico se explicaria a partir de uma crise do espaço público, que não mais seria capaz de fornecer aos indivíduos experiências de vida, mas somente vivências fugazes, desarticuladas, incapazes de compor uma narrativa. Christoph Asendorf ${ }^{8}$, retomando Walter Benjamin, localiza a morte da experiência pública no século XIX, nas cidades repletas de habitantes que teriam perdido a relação orgânica e artesanal com o trabalho. Como forma de compensação, o morador urbano teria se voltado para o espaço da casa, para nele constituir sua experiência, na forma de uma narrativa de vida constituída a partir dos objetos domésticos. Ao "colecionar" objetos, o morador construiria sua identidade, seu território psíquico, identificado por Freud nesse mesmo período como inconsciente e tão bem descrito por Proust na série literária Em Busca do Tempo Perdido. Se essa explicação hoje nos parece nostálgica e, por isso, pouco convincente, ela não invalida o fato notório de que o fenômeno de identificação dos interiores da casa e da mente realmente aconteceu e acontece até os dias de hoje. Daniel Miller vê no consumo capitalista a possibilidade de retirarmos do mercado objetos produzidos de forma homogênea (e com baixo custo, portanto acessíveis a mais pessoas) para individualiza-los no interior de nossas casas, por meio de arranjos e sentidos associados a nossas experiências de vida ${ }^{9}$. Susan Stuart considera o suvenir uma forma de transformar uma experiência de vida complexa e inabarcável em algo que se pode delimitar, deslocar e possuir - um memento incrustado a outros no interior de nossa decoração ${ }^{10}$. Desdobramentos dessa questão serão tratados no decorrer de nossa

p. 1-54.

7 RICE, Charles. The emergence of the Interior. London, New York: Routledge, 2007,

8 ASENDORF, Christoph. Batteries of Life: On the History of Things and Their Perception in Modernity (Weimar and Now: German Cultural Criticism). California: University of California Press, 1993.

9 MILLER, Daniel. Extracts from Material Culture and Mass Consumption. In: BUCHLI, Victor. Material Culture: Critical Concepts in the Social Sciences. London, New York: Routledge, 2004, v. II, p. 292-336.

10 STEWART, S. On Longing: Narratives of the Miniature, the Gigantic, the Souvenir, the Collection. Durham, Duke University Press, 1993. 
análise. O que importa agora é justificar nosso interesse em certo tipo de objeto utilizado no interior doméstico.

A segunda justificativa refere-se às vinculações de tais artefatos a uma grande família de imagens (e consequentemente de práticas) que circularam (e ainda circulam) em níveis mundiais, consumidas por adultos e crianças. Nesta perspectiva, o que se afirmará será sempre uma expectativa ou um potencial de sentidos perceptíveis na produção dessas imagens e nas respostas bem sucedidas de seu consumo e difusão. Estamos convictos de que há uma ligação muito estreita entre as imagens de cenas de cortesia com os filmes de princesas produzidos pela Walt Disney. Delimitaremos nossa análise a dois filmes, Branca de Neve e os Sete Anões (1937) e Cinderela (1951). Em 1937, Walt Disney lança o primeiro filme longa metragem da Disney, no nosso entender o mais desafiador, inovador e complexo em sua narrativa, o que justifica sua escolha para análise. Cinderela é o segundo filme de sucesso, o primeiro do pós-guerra e também aquele em que mais se evidenciam as inspirações setecentistas.

Nosso objetivo é demonstrar como Walt Disney elevou à condição de consumo de massa sentidos de feminilidade constituídos a partir da apropriação de repertórios de um passado histórico idealizado. $\mathrm{O}$ uso do repertório setecentista foi, no nosso entender, obscurecido pelas evidências explícitas a citações do medievo ${ }^{11}$, não tendo sido considerado pelos estudiosos apesar da importância estratégica do século XVIII na valorização das habilidades femininas, constituídas nesse período como nobilitantes, justamente por não estarem associadas ao trabalho.

Nossa hipótese central é a de que o repertório de técnicas corporais e de artefatos setecentistas, especialmente aquele desenvolvido no âmbito da aristocracia francesa, migrou para as mulheres abastadas e de classe média dos séculos XIX e XX, servindo para constituir um discurso sobre a importância da mulher como dona de casa e mãe de família ${ }^{12}$. Os filmes da Disney teriam

11 PUGH, Tison; ARONSTEIN, Susan (ed.). The Disney Middle Ages. A Fairy-Tale and Fantasy Past. New York: Palgrave Macmillan, 2012.

12 MONTGOMERY, M. E. Displaying Women: spectacles of Leisure in Edith Wharton's New York. London/New York: Routledge, 1998; VEBLEN, T. Teoria da classe ociosa. 
concorrido para a atualização e expansão desses valores. O caráter conservador e mesmo reacionário no tratamento das personagens femininas já foram apontados em inúmeros trabalhos acadêmicos ${ }^{13}$. No entanto, estes filmes não foram ainda analisados do ponto de vista da cultura visual e material. Tal análise nos oferece a possibilidade de irmos além dos aspectos ideológicos contemporâneos ao lançamento dos filmes para compreendermos as matérias-primas visuais e materiais desse discurso. A abordagem aqui proposta difere igualmente de outra vertente de trabalhos sobre a Disney, que procurou identificar as apropriações que os filmes fizeram de referências artísticas sincrônicas e diacrônicas, sem, no entanto, relacionar as citações artísticas às dinâmicas socioculturais.

\section{As cenas de cortesia e a sociabilidade feminina no século XVIII}

A esta altura seria bom explicarmos o que são as cenas de cortesia. Nascidas na França do século XVIII, no interior do estilo rococó, as representações conhecidas como fête galante estão na origem dos artefatos aqui em foco. As fêtes galantes foram produzidas, em parte, por encomenda da aristocracia francesa que, após a morte de Luís XIV (1638-1715), deixara Versalhes para viver em Paris. Seus expoentes foram pintores como Antoine Watteau,

São Paulo: Abril Cultural, 1983; McKENDRICK, Neil at alii. The Birth of a Consumer Society. The Commercialization of Eighteenth-Century England. Bloomington: Indiana University Press, 1982; LEARS, Jackson. Beyond Veblen: Rethinking Consumer Culture in America. In: BRONNER, Simon J. Consuming Visions: Accumulation and Display of Goods in America, 1880-1920. Winterthur Delaware: The Henry Francis du Pont Wintertthur Museum, New York: London: WWNorton \& Company, 1989, p. 73-97.

13 VOGEL, Sarah. How can they tell if I am male or female? Gender stereotypes in Disney movies. Norderstedt Germany: Grin Publishing, 2015; HENIGIN, Lisa. Gender-specific Speech in Disney Animated Movies. Language as an Indicator of Female Inferiority and Politeness. Norderstedt Germany: Grin Publishing, 2016; KRAPFENBAUER, Eva-Marie. The same old story? The portrayal of gender and ethnicity/race in Disney movies and the possible (re)production of stereotypes over the course of the past 75 years. Bachelor Tesis. Norderstedt Germany: Grin Publishing, 2013. 
Nicolas Lancret, François Boucher, Jean-Baptiste Pater, Jean-Honoré Fragonard, que se dedicaram a recriar cenas ao ar livre da nobreza francesa exercendo o "ócio produtivo", segundo feliz expressão de Mimi Hellman ${ }^{14}$. Nas fêtes galantes, os elementos naturais estão organizados para indicar a existência de uma perfeita harmonia com os seres humanos, que se entretêm dançando, caçando, colhendo frutos, representando trechos de peças de teatro, consumindo alimentos e bebidas, jogando ou simplesmente usufruindo da companhia de seus pares. Observamos nestas composições a presença graciosa e mesmo erótica dos corpos. Vislumbramos o que Vigarello identificou como "sentimento de si", encetada pelos ideais iluministas e que logo alcançaria as representações artísticas. Nesse momento, a percepção da dimensão individual se desloca de um sujeito abstrato para a de um sujeito carnal. Encapsulado por uma mente racional ou por uma alma sagrada, a noção de si tinha o corpo como uma contingência ambígua. Ao mesmo tempo em que era tocado pela santidade da alma e pela pureza da razão descarnada, ele precisava ser protegido das profanações pecaminosas ou dos perigos da insanidade. Os cinco sentidos serviam, nas palavras de Vigarello, como sentinelas. Eram entendidos como uma barreira contra agressões vindas do mundo externo e terrestre, contra perigos iminentes de toda sorte propiciados pelo contato com o mundo natural ou ardilosamente perpetrados nas relações humanas. Mas, no século XVIII europeu, a alma cede lugar a um corpo que usa seus sentidos como ferramenta para perscrutar os sentimentos, ou seja, para sentir a si mesmo. O ser etéreo é marginalizado para dar protagonismo ao ser carnal, qualidade antes vista como simples contingência, tratada como curiosidade ou perplexidade nos casos mais radicais de sua manifestação, como a loucura, mas que agora se tornara sistematicamente observada,

14 HELLMAN, Mimi. Furniture, Sociability, and the Work of Leisure in EighteenthCentury France. Eighteenth-Century Studies, vol. 32, n. 4, 1999, p. 415-445; HELLMAN, Mimi. Interior Motives: Seduction by Decoration in Eighteenth-Century France. In: KODA, H. \& BOLTON, A. Dangerous Liaisons: Fashions and Furniture in the Eighteenth Century. New York/London: The Metropolitan Museum of Art/Yale University Press, 2004, p.15-23.

15 VIGARELLO, Georges. $O$ sentimento de si: História da percepção do corpo. Petrópolis: Vozes, 2016. 
discutida e representada (figura 1). Esta mudança sustentou o hedonismo consumista que se desenvolveu a partir do século XIX.

\section{Figura 1}

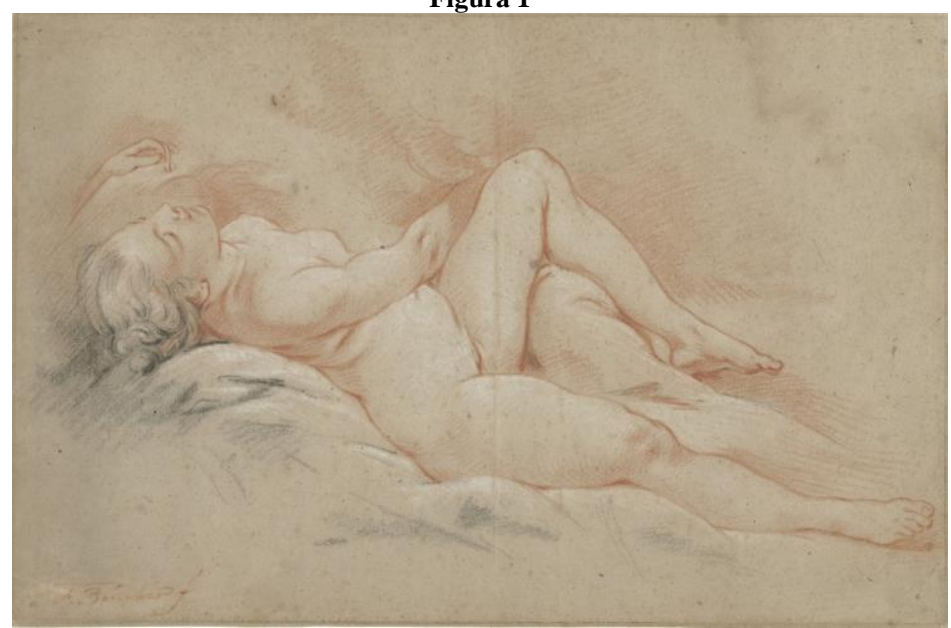

$\mathrm{Nu}$ feminino recostado, François Boucher, 1713-1754, 30x46 cm, pastel em preto, branco e vermelho. Acervo do Rijskmuseum, Amsterdã, Holanda.

As fêtes galantes oferecem exemplos notáveis dessa explosão sensorial, que não surgiu da simples especulação filosófica. Ao contrário, estava ancorada em formas sofisticadas de relacionamento da aristocracia, especialmente a francesa, em que as experiências sensoriais associavam-se a performances de sedução de toda ordem verbal, corporal e visual ${ }^{16}$ (figura 2).

16 Além das obras de Mimi Hellman já referenciadas, ver também BREMER-DAVID, Charissa (ed.). Paris: Life \& Luxury in the Eighteenth Century. Los Angeles: The J. Paul Getty Museum, 2011. 


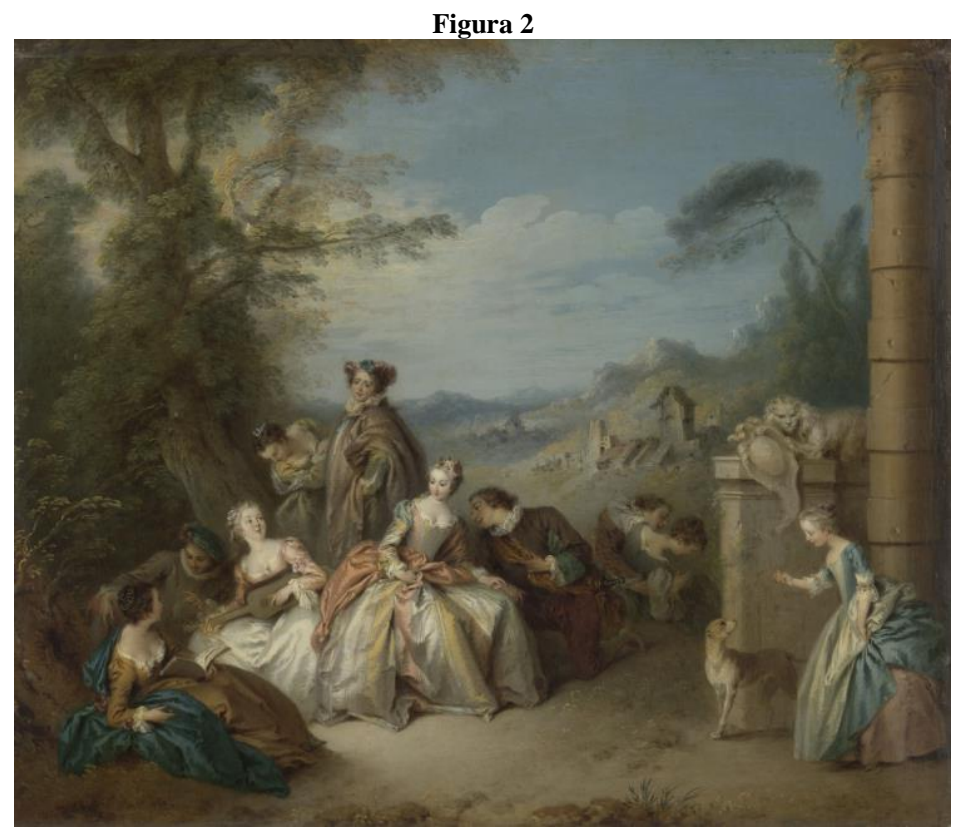

Fête galante na paisagem, Jean Baptiste François Pater, c. 1730-35, óleo sobre tela, $50,5 \times 60,5 \mathrm{~cm}$. Acervo do Rijskmuseum, Amsterdã, Holanda.

Vários autores, que se dedicaram a compreender a sociabilidade aristocrática francesa, identificaram uma alquimia importante entre artificialismo e naturalidade ${ }^{17}$. Os artefatos produzidos para decoração no estilo rococó nos mostram bem como a simbiose entre o natural e o artificial resultou em paisagens entremeadas a ruinas inspiradas no renascimento greco-romano. Esta aproximação aparentemente paradoxal está presente também na seleção do que é a natureza - pequenas árvores, arbustos e relva que se moldam para enquadrar e abrigar a cena do encontro. Flores, animais amistosos, incluindo a emblemática ovelha, transformam os

17 Joan DeJean, Mimi Hellman, Peter Björk Kerber, Kimberly Chrisman-Campbell, Charissa Bremer-David, Caroly Sargentson, entre outros. 
fidalgos em pastores de um mundo idílico e atemporal (figura 3). As flores eram especialmente representadas com forte realismo, como réplicas da Natureza, elas eram a demonstração da imensa habilidade do artista em produzir com massa de areia e pigmentos uma impressão de naturalidade. A proeza do artificialismo estava justamente em fazer passar por natural o que foi constituído por meio de um longo trabalho de educação dos sentidos e treinamento técnico (figura 4).

Figura 3

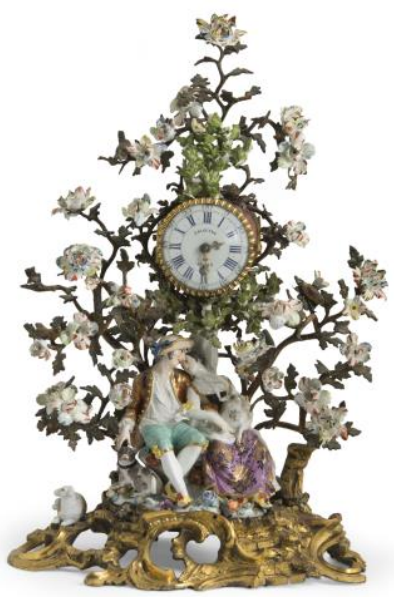

Relógio, criação de François Leloutre, manufatura Meissen, flores e figuras (pastores, ovelhas e cão) em porcelana, estruturas e base de bronze dourado e cinzelado, 51,5x35x23 cm, séc. XVIII, Paris, França. Paris, Les Arts Décoratifs, musée des Arts décoratifs. CParis, Les Arts décoratifs/ Cyrille Bernard. Notar as faces rosadas dos pastores, à moda da maquiagem da nobreza do período.
Figura 4

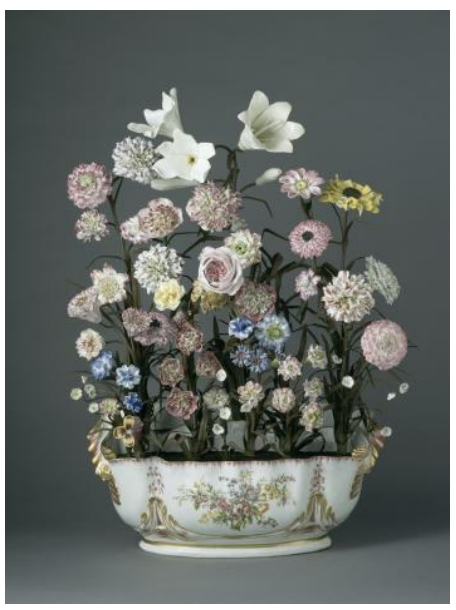

Manufatura real de Vincennes, buquê de flores em uma jardineira, porcelana, c. 1752, Martine Beck-Coppola. A Manufatura de Vincennes, criada em 1740, se transforma em 1756 na Manufatura de Sèvres. Coleção de porcelana europeia do Musée national de ceramique de Sèvres. Cité de la ceramique Photo (C) RMN-Grand Palais. 
As cortes germânicas, anglo-saxônicas e as elites de comerciantes abastados dos países baixos, que se orientaram segundo a ética protestante, contiveram e combateram a extravagância do artificialismo em prol de uma simplicidade física compreendida como espelho da pureza e rigor moral do $\operatorname{ser}^{18}$. A aristocracia francesa, livre das amarras calvinistas e do rigor religioso das cortes ibéricas, pode construir uma aparência artificial vivida com naturalidade segundo os códigos de uma etiqueta fortemente performática, em que a vida em sociedade era compreendida como uma oportunidade de atuação teatral. Objetos em interação com as habilidades do corpo e a erudição intelectual do indivíduo eram vistos como elementos cenográficos que concorriam para a obtenção ou perda de prestígio do ator social $^{19}$. Até mesmo a rarefação da iluminação a velas e lamparinas servia para testar a habilidade social e atestar a capacidade financeira do anfitrião, não apenas pela quantidade de chamas que se mantinham acessas, ou pela dimensão e número de espelhos que amplificavam a luz, mas também pela presença de molduras, pés e quinas do mobiliário coberto com ferragens modeladas em relevos a ouro, que brilhavam nos ambientes em penumbra, sinalizando o espaço para a melhor movimentação dos presentes e exacerbando o prestígio de seus proprietários. Nesse mesmo sentido, as joias mais consideradas eram aquelas confeccionadas em intrincados arranjos em laços e relevos de múltiplas gemas, cujas inclinações e lapidações multiplicavam o seu brilho em ambientes com pouca luz. Funções semelhantes cumpriam os serviços de banquete em prata e ouro ${ }^{20}$. As mesas de jogos, tão comuns nesse estrato social, tinham locais para manter candelabros acessos para que a diversão pudesse se estender por mais tempo, o que obrigava seus participantes a sentarem-se

18 Pensamento que estará na base de todos os discursos da funcionalidade da forma, aplicado tanto à arquitetura, à arte, aos interiores residenciais e à moda. Ver BRONNER, Simon J. Consuming Visions: Accumulation and Display of Goods in America, 1880-1920. Winterthur Delaware: The Henry Francis du Pont Wintertthur Museum, New York: London: WWNorton \& Company, 1989.

19 Bem à maneira de GOFFMAN, Erving. A representação do Eu na vida cotidiana. Petrópolis: Vozes, 1985.

20 HELLMAN, Mimi. Enchanted Night: Decoration, Sociability, and Visuality after Dark. BREMER-DAVID, Charissa (ed.). Paris: Life \& Luxury in the Eighteenth Century. Los Angeles: The J.Paul Getty Museum, 2011, p. 91-113. 
muito perto uns dos outros. A iluminação próxima ao rosto exigia um maior controle facial e de gestos:

'É necessário moderar o jogo e moderar-se ao jogar. Aqueles que jogam com paixão, ganância e interesse próprio muitas vezes se esquecem disso; ficam impacientes, maldizem, ficam de mau humor quando o jogo se vira contra eles, revelando-se a baixeza de seus sentimentos'. As chamas de velas materializariam tais lapsos, intensificando seu brilho em resposta ao vigoroso suspiro de aborrecimento de um perdedor ou transformando o sorriso triunfante de um vencedor em um grotesco arreganhar de dentes. As mesas de jogos convenientemente iluminadas não facilitavam apenas o entretenimento, elas também expunham os lapsos comportamentais e desafiavam os usuários a jogar prazerosamente ao mesmo tempo que conscientes de sua autocontenção. ${ }^{21}$ (tradução da autora)

$\mathrm{O}$ alto grau de refinamento da aristocracia parisiense era conhecido nas demais cortes europeias, não ficando imune a críticas. No entanto, o investimento francês na sofisticação das regras de convívio não se deveu a uma inerente afeição ao luxo. Ao contrário, ele forjou-se como reação ao recrudescimento das disputas por prestígio no topo da pirâmide social ${ }^{22}$. O progressivo colapso das fortunas nobiliárquicas associado ao crescimento político, intelectual

21 "It is necessary to moderate one's game, and to moderate one-self while playing. Those who play with passion, greed, and self-interest often forget themselves; they become impatient, they curse, they are bad-tempered when the game turns against them, and they disclose the baseness of their sentiments. Candle flames would materialize such lapses, flaring in response to a loser's vigorous sigh of annoyance or turning a winner's triumphant smile into a grotesque grin. Conveniently lit game tables did not simply facilitate entertainment, they also exposed behavioral lapses and challenged users to play with pleasingly self-conscious restraint. Op. cit. p. 102-3. O primeiro trecho da citação é de Jean-Baptiste Morvan de Bellegarde, da obra Les Refléxions sur le ridicule, et sur les moyens de l'éviter (1723), citado por Hellman, seguido de suas observações sobre o uso da mesa de jogos.

22 HELLMAN, Mimi. Furniture, Sociability, and the Work of Leisure in EighteenthCentury France. Eighteenth-Century Studies, vol. 32, n. 4, 1999, p. 415-445. 
e econômico de Paris $^{23}$ impulsionaram o enriquecimento extraordinário de comerciantes, ávidos pelo consumo de bens de luxo, acertadamente identificados como o capital simbólico necessário para legitimar a nova classe ascendente de burgueses.

As esculturas do gênero fête galante colaboraram na difusão dos costumes aristocráticos. Os pintores que praticavam este gênero estavam muito próximos das manufaturas de porcelana, produzindo protótipos para elas e também para gravuristas, que fizeram suas imagens alcançarem um raio de circulação extraordinário. Além disso, os moldes feitos para as empresas de porcelana ficavam arquivados, podendo ser novamente recuperados, ao longo de muito tempo, para uma nova reprodução ou para inspirar outros artistas ${ }^{24}$.

A mobilidade social e o acesso aos bens de luxo antes restritos à alta aristocracia nos ajudam a responder às perguntas colocadas inicialmente neste artigo. Como sabemos, o longo processo de ascensão da burguesia estava apenas em seu início. A apropriação do que antes era de uso exclusivo da aristocracia fazia parte dos anseios dos novos ricos ${ }^{25}$. No jogo em que se transformaram as disputas sociais, as mulheres, sutilmente e de modo estratégico, estiveram na linha de frente, fenômeno que não passará impune às recomposições de forças e poderes que viriam a reger as futuras distinções de gênero que conheceremos nos séculos XIX e XX.

Acreditamos que Kimberly Chrisman-Campbell tenha detectado o momento em que as mulheres ganharam protagonismo nas disputas por signos de nobilitação e, com isso, passaram a chamar para si a atenção dos $\operatorname{artistas}^{26}$. A autora reconhece que tanto homens quanto mulheres aristocratas exibiam luxo e ornamentos intensamente - os mesmos tecidos, cores, materiais aplicados (fios de ouro, prata e pedrarias), técnicas de bordados e temas ornamentais eram utilizados

23 A cidade de Paris, em 1793, contava com mais de 640 mil habitantes. http://cassini.ehess.fr/cassini/fr/html/fiche.php?select_resultat=26207

24 WILHELM, Peter \& REBER, Horst. La porcelaine européenne du XVIIIe. Siècle. Fribourg/Suisse: Office du Livre, 1980.

25 UNRUH, Allison. Aspiring to la Vie Galante: Reincarnations of Rococo in Second Empire France. Tese de doutorado (Institute of Fine Arts), New York, New York University, 2008.

26 CHRISMAN-CAMPBELL, Kimberly. Dressing to Impress: the Morning Toilette and the Fabrication of Femininity. BREMER-DAVID, Charissa (ed.). Paris: Life \& Luxury in the Eighteenth Century. Los Angeles: The J.Paul Getty Museum, 2011, p. 53-73. 
por ambos os gêneros. No entanto, Christman-Campbell nota a preponderância da figura feminina em cenas de toalete nas pinturas francesas do século XVIII. O momento da toalete, instituído como ritual por Luís XIV e praticado por homens e mulheres aristocratas e da alta burguesia, consistia na preparação do corpo para a vida social $^{27}$. Amparada por serviçais e assistida por uma plateia que poderia incluir familiares, amigos íntimos, fornecedores, credores, agentes religiosos e comerciantes, a toalete era considerada fulcral na exposição de bom gosto, habilidade social, prestígio e poder econômico. Uma parte do ritual consistia na aplicação de maquiagem que, apesar de comum na aristocracia, neste período assume características peculiares, que diziam respeito à higiene, à beleza e ao rejuvenescimento. A pele passava por uma limpeza e cobertura de massa branca de chumbo. Após essa aplicação, que escondia imperfeições, manchas, além de clarear o rosto, nele se aplicava com pincéis o ruge na forma de circunferências sobre as maçãs do rosto. $\mathrm{O}$ cabelo era untado com pomada ${ }^{28}$ que servia para moldá-lo e perfumá$10^{29}$, além de criar uma superfície aderente para a aplicação do pó branco também perfumado ${ }^{30}$. A cena de toalete era uma das mais prestigiadas na pintura por causa do alto custo do espelho e dos acessórios que a acompanhavam, confeccionados em prata, ouro ou porcelana. Mães foram retratadas com suas filhas em frente às suas penteadeiras e noivas ao lado de seus noivos, responsáveis pelo serviço de toalete oferecido como presente de casamento.

Mimi Hellman e Chrisman-Campbell notam a identificação dos artefatos das elites do séc. XVIII com suas vestimentas. No caso das penteadeiras e suas guarnições, "fitas, flores, penas, pentes, cosméticos, rendas, pérolas, pó, rouge e enfeites migram da mesa de toalete para o corpo e vice-versa em uma troca contínua"31. A

27 Kimberly Chrisman-Campbell nos explica que a toalete era dividida em dois momentos, aquele estritamente privado, em que o corpo era coberto e vestido, e aquele longo e público, em que acessórios eram colocados e as finalizações da toilete eram feitas. Op. cit. p. 54.

28 Produzida usualmente com gordura animal ou óleo de amêndoa e maçãs, daí o nome "pomada", do francês pommes (maçãs). Op. cit. p.62.

29 Com essências de laranja, limão, lima, jasmim e bergamota. Op. cit. p. 62.

$30 \mathrm{O}$ uso de pó branco nos cabelos virou moda e teve início como uma homenagem aos cabelos brancos de Luís XIV. Ajudava a disfarçar a idade. Op. cit. p.62.

31 "[...] ribbons, flowers, feathers, combs, cosmetics, lace, pearls, powder, rouge and patches migrate from the toilette table to the body and back in a seamless exchange”. Op. cit. p. 65. 
interação da toalete feminina com a pintura ia além da sua incidência nas telas francesas, os pigmentos usados na maquiagem eram os mesmos usados para o retrato, e a preparação da pele em muito se aproximava da preparação da tela. Chrisman-Campbell nos oferece uma extraordinária análise do Retrato de Madame Marsollier e sua filha, realizado por Nattier (figura 5). Madame Marsollier era uma aristocrata da baixa corte casada com um rico comerciante de tecidos.

Figura 5

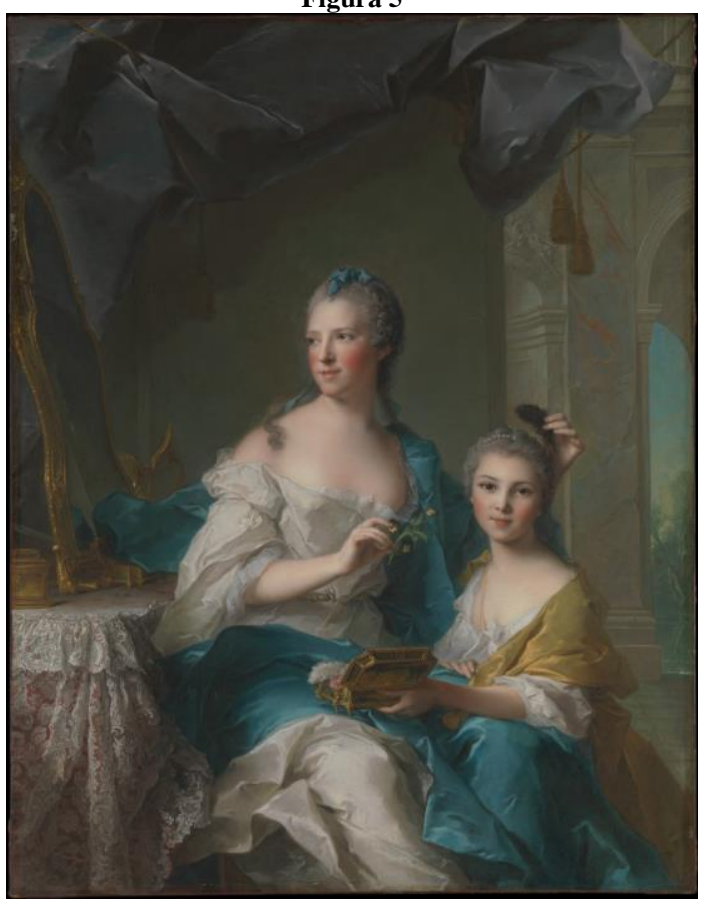

Madame Marsollier e sua filha, Jean Marc Nattier, 1749, óleo sobre tela, 14,61x11,43 cm, doação de Florence S. Schuette em 1945. Acervo do Metropolitan Museum of Art, NY-USA. https://creativecommons.org/publicdomain/zero/1.0/

O retrato teria sido uma forma encontrada por Marsollier de "reabilitar sua imagem", rebaixada pelo casamento fora da aristocracia. A decisão de fazer seu retrato em toalete já fazia parte 
dessa reabilitação, posto que a cena fosse típica das mulheres nobres. Ao mesmo tempo, o retrato, exibido no Salão de 1750, tornara-lhe possível expor seus pertences de alto custo como a mesa coberta com toalha rendada, parte do serviço de toalete, o espelho e os tecidos luxuosos que envolvem mãe e filha. Os tecidos em cetim não foram utilizados para indicar uma indumentária específica, ao contrário, eles estavam na cena para associar as duas mulheres às representações alegóricas, atemporais e sensuais, uma especialidade de Nattier. $\mathrm{Na}$ pintura percebemos o uso do pó branco nos cabelos, a cobertura do rosto e colo com a pasta branca de chumbo e as circunferências de ruge nas maçãs do rosto das duas mulheres. Além da vontade de Marsollier de se mostrar apta a acompanhar a moda francesa das altas elites, para Chrisman-Campbell, o espelho e a filha refletem a beleza da mãe, aplacando-se dessa forma uma suposta inveja desta em relação àquela, mais jovem ${ }^{32}$.

Três características ressaltadas por Chrisman-Campbell nos interessam aqui. A primeira diz respeito ao fato de que os homens franceses, que, na segunda metade do séc. XVIII, ainda dedicavam muito tempo à toalete, começaram a ser considerados efeminados ${ }^{33}$. A percepção social era a de que esses hábitos e, com eles, a forte ornamentação corporal, eram próprios das mulheres. A sua prática por homens era interpretada como consequência de um aprendizado junto às mulheres, decorrente de um convívio demasiado, julgado inconveniente. Para a autora, uma explicação possível é a de que os homens passaram a dedicar mais tempo a outras atividades de negócios e ócio, já que sua toalete era mais simples de ser feita do que a das mulheres ${ }^{34}$. Por outro lado, a percepção do ócio aristocrata começava a mudar rapidamente com a expansão do estilo de vida burguês, em que o homem constrói seu prestígio por meio da grandeza de uma fortuna amealhada com o trabalho. A segunda característica ressaltada por Chrisman-Campbell, diz respeito ao

$32 \mathrm{O}$ sentimento da inveja da mãe da beleza da filha era tema recorrente na literatura e teatro franceses. Op. cit. p.67.

33 Os exemplos de homens franceses fazendo toalete se tornaram raros, mais presentes como sátiras ou de origem estrangeira. Op. cit. p. 67.

34 Os homens não moldavam os cabelos, mas usavam perucas. Op. cit. p. 67. Sobre o uso de perucas no séc. XVIII ver POINTON, Marcia. Hanging the Head. Portraiture and social formation in Eighteenth Century England. London/New Haven: Yale University Press, 1993. 
simbolismo das pinturas de toalete. Elas traziam marcadores da passagem do tempo, como velas queimando, relógios e o próprio espelho, dando a entender que a beleza era efêmera ${ }^{35}$. A terceira característica presente nas representações de toalete feminina era a de que se reconhecia nesta prática e especialmente no uso de maquiagem a possibilidade de transformação da mulher durante o dia, quando ela poderia não só rejuvenescer, mas se tornar bela.

Em resumo, notamos o surgimento de um discurso sobre a juventude e a beleza associado à mulher. Estamos em um momento em que a maquiagem devia ser notada, para servir como signo de distinção aristocrática, ao mesmo tempo em que ela camuflava o envelhecimento feminino. Os mecanismos de produção da sociabilidade aristocrática francesa começam a ser colocados em xeque pela austera moralidade protestante, outra fonte de valores da burguesia, tornando-se, inclusive, dificultosa a compreensão de seu funcionamento e pertinência. Aspectos importantes das atividades femininas e também masculinas e que dizem respeito às interações sociais que aconteciam no quarto, no momento da toalete, são deixados de lado. Os móveis portáteis e multifuncionais, feitos sob encomenda, descritos por Mimi Hellman, são prova de como a toalete poderia abarcar múltiplas atividades ${ }^{36}$. O ócio produtivo, pouco a pouco, transforma-se em frivolidade associada à figura feminina.

$\mathrm{O}$ ato de vestir (e arrumar os cabelos) foi excepcionalmente complicado e participativo na França do meio do século XVIII. Uma longa toalete não implicava necessariamente um desperdício autoindulgente das horas da manhã. Ao contrário, foi precisamente porque a fabricação da feminilidade elegante levava tanto tempo que muitas mulheres de elite socializavam e tratavam de negócios durante a toalete. Op. cit. p. 54.

35 A percepção do período era a de que a juventude feminina terminava aos trinta anos.

36 Mimi e Chrisman-Campbell, op. cit. p. 71 e SARGENTSON, Carolyn. Inside the Interior: Furniture and Its Inner Spaces in 18th Century France.In: AYNSLEY, Jeremy e GRANT, Charlotte (ed.). Imagined Interiors: representing the domestic interior since the renaissance. London: V\&A Publications, 2006, p.130-1. 
[...] Era durante suas toaletes que as mulheres liam livros, escreviam cartas, faziam o desjejum, compraram, entretinham-se e aprendiam música e línguas. ${ }^{37}$ (tradução da autora)

A sedução do outro era o resultado de uma performance complexa, em que escolhas da moda associadas ao bom gosto, gestos e movimentos corporais graciosos, as habilidades no manuseio de artefatos e mobiliários multifuncionais, as aplicações de adereços e de maquiagem de acordo com a moda entre os nobres, a forma de exibir a riqueza dos equipamentos e do mobiliário, tudo concorria para que homens e mulheres aristocratas fossem percebidos como seres diferentes dos demais. Não era, portanto, apenas a exibição de partes do corpo desnudo a responsável pelo poder de sedução dessas mulheres ${ }^{38}$.

\section{Interiores e interioridade}

Joan DeJean situa na aristocracia francesa o início de experiências de conforto e privacidade. As plantas tradicionais dos palácios residenciais, seguindo a matriz italiana, eram desenhadas de modo a enfileirar os cômodos e alinhar suas portas. Dessa forma, alguém que estava no salão de entrada poderia avistar salões intermediários, gabinetes e até mesmo o quarto. Todos os espaços tendiam a ser públicos, apesar das restrições aplicadas ao acesso físico. No transcorrer do século XVIII, na França, as plantas começaram a apresentar parte de seus cômodos separados da área pública. Eles eram concebidos menores, de modo a reter o calor, e eram ainda de acesso difícil para o visitante. As portas deixaram de ser alinhadas e surgiram acessos camuflados para facilitar a

37 Chrisman-Campbell, op. cit. p.71.

38 A mais poderosa delas foi Mme Pompadour. Op. cit. p.71. 
circulação dos empregados e dos proprietários longe das vistas de visitantes ${ }^{39}$.

No entanto, a ideia de intimidade associada ao espaço da casa, como já anunciamos anteriormente, é um fenômeno do século XIX, em que se fundem o espaço interior concreto e o espaço imaginário de seu habitante ${ }^{40}$. As descobertas aristocráticas do conforto foram reapropriadas por um espectro social muito mais amplo, para o qual se tornara possível a constituição de mundos alternativos ao trabalho e ao espaço público. Os interiores românticos europeus estão na base de processo. Eles foram alimentados por objetos dispersos que estavam em igrejas e palácios ou mesmo por aqueles encontrados em escavações arqueológicas. Considerados "antiguidades", tinham sido reunidos por colecionadores e comerciantes durante os séculos XVII e XVIII. Os falecimentos sem herdeiros, a dispersão das heranças, as ruínas financeiras desses colecionadores ou de suas famílias alimentaram no século XIX um mercado ampliado, em que aos objetos de origem greco-romana somavam-se aqueles de origem local, associados à valorização da cultura nacional. Estas coleções passaram a ser uma ambição possível para pessoas com recursos financeiros mais restritos, capazes de encontrar objetos de interesse em mercados mais baratos e mais próximos $^{41}$.

39 DEJEAN, Joan. A New Interiority: The Architecture of Privacy in EighteenthCentury Paris. BREMER-DAVID, Charissa (ed.). Paris: Life \& Luxury in the Eighteenth Century. Los Angeles: The J.Paul Getty Museum, 2011, p.33-51. Da mesma autora ver $O$ século do conforto: quando os parisienses descobriram o casual e criaram o lar moderno. Rio de Janeiro: Civilização Brasileira, 2012.

40 AYRES, William S. Pictures in the American Home, 1880-1930. In: FOY, Jessica H.; MARLING, Karal Ann. The Arts and the American Home, 1890-1930. Knoxville: The University of Tennessee Press, 1994, p. 149-164; GORDON, Beverly. Cozy, Charming, and Artistic: Stitching Together the American Home. In: FOY, Jessica H. e MARLING, Karal Ann. The Arts and the American Home 1890-1930. Knoxville: The University of Tennessee Press, 1994, p. 124-148; MARLING, Karal Ann. From the Quilt to the Neocolonial Photograph: The Arts of the Home in an Age of Transition. In: FOY, Jessica H.; MARLING, Karal Ann. The Arts and the American Home, 1890-1930. Knoxville:The University of Tennessee Press, 1994, p. 3.

41 CLIVE, Wainwright Clive. The Romantic Interior. The British Collector at Home. 1750-1850, New Haven/ London: Paul Mellon Centre for Studies in British Art/ Yale University Press, 1989. 
No contexto europeu, as características das coleções domésticas organizadas por homens no século XVIII e início do século XIX podem ser assim resumidas: o gosto por objetos antigos (clássicos, renascentistas e, depois, medievais, devido ao interesse pela identidade nacional que incentivou a busca das raízes culturais no próprio país, ou ainda exóticos como objetos chineses, japoneses ou persas); a lógica pouco discernível, oriunda de critérios estéticos e afetivos vinculados a um arranjo extremamente personalizado; a tendência ao acúmulo e a prática de expor ao público estes objetos, mesmo estando alocados em espaços residenciais. Tal perfil indica que as coleções decorativas domésticas organizadas por homens foram uma das matrizes dos ambientes domésticos do final do século XIX, não mais regidos por homens que tinham prazer em colecionar, mas, agora, organizados basicamente por mulheres, que tratavam de constituir, através do arranjo de mobiliário e objetos na casa, um mundo alternativo àquele do trabalho urbano. ${ }^{42}$

A fusão do espaço doméstico com a personalidade de seu proprietário $^{43}$ não teve como consequência exclusiva a ostentação ou mesmo a afirmação de uma identidade individual em oposição às demais. Esta fusão permitiu que houvesse uma retroalimentação entre o espaço concreto e o espaço ficcional. Processo que não ficou alheio, muito ao contrário, à disseminação do hábito de ler e ao surgimento do romance. Examinando novelas e romances entre 1720 e 1920, Charlotte Grant percebe a proliferação de expressões linguísticas metafóricas que utilizavam objetos e espaços da casa para descrever "paisagens" da mente. A manifestação literária surgiu ao mesmo tempo em que cresceram as guarnições dos interiores domésticos. Nas

42 CARVAlHO, Vânia Carneiro de. Gênero e artefato. O sistema doméstico na perspectiva da cultura material. São Paulo: EDUSP/Fapesp, 2008, p. 181-216.

43 HALTTUNEN, Karen. From Parlor to Living Room: Domestic Space, Interior Decoration, and the Culture of Personality. In: Simon J. Bronner. Consuming Visions: Accumulation and Display of Goods in America 1880-1920. New York, London: W.W. Norton \& Company, 1989, p.157-189. 
palavras de John Lukacs, "O mobiliário do interior das casas apareceu junto com o mobiliário do interior das mentes" 44 .

O hábito de ler histórias ficcionais próximas ao nosso cotidiano, que investigavam os sentimentos de seus personagens, tornara-se agente no processo de criação desse novo território psíquico. Imaginação, imagens, objetos e espaços da casa vincularamse como se fizessem parte de uma mesma estrutura que foi, então, impulsionada e fortalecida pelo mercado de consumo. A escultura de porcelana inspirada no gênero fête galante, mas produzida no século XIX, mostra bem a mudança de comportamento. Nela, a figura feminina adormece e o livro, aberto, tomba de sua mão. Estaria a moça sonhando com seu bem amado? Ele se aproxima e a ligação amorosa fica sugerida pela justaposição do chapéu ao buque de flores à esquerda da cena (Figura 6). Diferentemente, a moça que na tela de Jean Baptiste Pater porta um livro, igualmente aberto, conversa com a figura masculina ao seu lado, talvez narrando uma história, talvez estejam em um momento de mútua sedução, mas nesta cena ninguém está sonhando, o que interessa e está sugerido na ação de todos os personagens é o exercício da sociabilidade (Figura 7).

44 "The interior furniture of houses appeared together with the interior furniture of minds". John Lukacs apud GRANT, Charlotte. 'One's Self, and One's House, One's Furniture': From Object to Interior in British Fiction, 1720-1900. AYNSLEY, Jeremy e GRANT, Charlotte (ed.). Imagined Interiors: representing the domestic interior since the renaissance. London: V\&A Publications, 2006, p.134-7. 


\section{Figura 6}

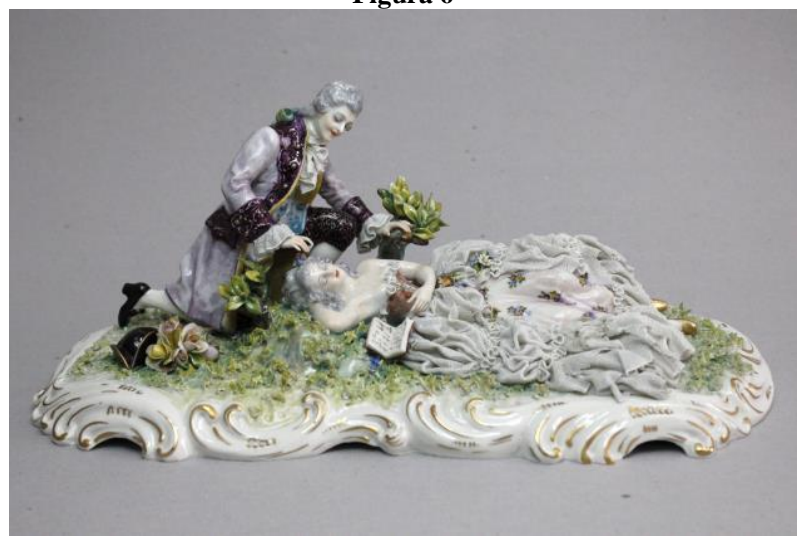

Casal de aristocratas, escultura de porcelana, estilo Capodimonte, século XIX, Itália. Fotografia de José Rosael. Acervo do Museu Paulista da Universidade de São Paulo.

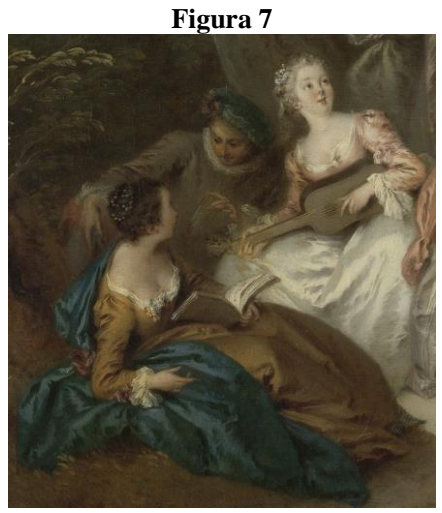

Detalhe da pintura Fête galante na paisagem, Jean Baptiste François Pater, c. 1730-35, óleo sobre tela, $50,5 \mathrm{x} \quad 60,5 \mathrm{~cm}$. Acervo do Rijskmuseum, Amsterdã, Holanda (ver Figura 2).

Estas parecem ter sido as mudanças de percepção e comportamento que propiciaram que repertórios de objetos e técnicas corporais do passado pudessem ser reapropriados de modo a alimentar os sistemas domésticos, agora entendidos como espaços de desenvolvimento, ao infinito, da própria subjetividade. 
Mas não se tratou apenas de uma livre combinação de elementos dessas diferentes dimensões - concreta e imaginária. A força de veracidade dessas recomposições se deve a uma visão teleológica do passado, própria da aspiração por universalidade e naturalidade dos valores burgueses. A casa passou a ser compreendida como o lugar que possibilitava o desenvolvimento de uma subjetividade inerente ao ser humano. As opções por conforto e privacidade foram consideradas atemporais, em que bastava haver as condições necessárias para o seu florescimento. Foi assim que muitos estudos sobre o espaço doméstico buscaram no século XVII holandês o nascimento do processo de constituição do espaço da casa como o lugar da interioridade do sujeito e da família nuclear burguesa ${ }^{45}$. Witold Rybczynski, um dos expoentes desse pensamento, associava o nascimento das ideias de intimidade, bem-estar, lar e família à existência de condições materiais que ultrapassassem a simples sobrevivência. $\mathrm{O}$ autor observa que a população pobre da Idade Média tinha sua sensibilidade "embotada" pelas péssimas condições de vida, pobreza que perdurou para muitos até o século XX:

Os pobres moravam mal. Não tinham água ou saneamento, praticamente não tinham móveis ou objetos pessoais, e essa situação, pelo menos na Europa, durou até o século XX. Nas cidades, suas casas eram tão pequenas que a vida familiar ficava comprometida; estes casebres mínimos de um só cômodo eram pouco mais que abrigos para dormir. Só havia espaço para as crianças pequenas - as mais velhas eram separadas dos seus pais e iam trabalhar como aprendizes ou criados. A consequiência destas privações, segundo alguns historiadores, é que conceitos como 'lar' ou 'família' não existiam para estas almas sofridas. Falar de conforto e desconforto nestas circunstâncias é um absurdo; tratava-se de mera sobrevivência. ${ }^{46}$

45 RYBCZYNSKI, Witold. Casa: pequena história de uma idéia. Rio de Janeiro: Record, 1999; THORNTON, Peter. Authentic Decor: the Domestic Interior, 1620-1920. New York: Viking Penguin, 1984; PRAZ, Mario, An Illustrated History of Interior Decoration from Pompeii to Art Nouveau. London: Thames and Hudson, 1964. AYNSLEY, Jeremy e GRANT, Charlotte (ed.). Imagined Interiors: Representing the Domestic Interior since the Renaissance. London: V\&A Publications, 2006.

46 Op. cit. p. 37. 
Na contramão do desejo de universalização de tais valores, Heidi de Mare e os autores da coletânea organizada por Jeremy Aynsley e Charlotte Grant demonstraram que os sentidos das pinturas do setecentismo holandês não podiam ser compreendidos fora de seu contexto sincrônico de consumo. Uma análise detalhada das imagens indicou que a aparência de realismo na representação de cenas de interiores domésticos podia enganar se compreendidas com categorias históricas anacrônicas. Na pintura a óleo de Pieter Janssens Elinga, que leva o título Interior com um Cavalheiro, uma Mulher Lendo e uma Empregada (Figura 8), vemos o piso de mármore bicolor, muito presente nestas representações, e um espaço interno bem iluminado por causa das amplas janelas. Esta imagem foi interpretada como exemplo das práticas burguesas que só mais tarde atingiriam outros locais da Europa. No entanto, as autoras nos esclarecem que o piso geométrico de pedra era raro nas casas, porque era muito caro e mais frio que o piso de madeira. Sua representação por Pieter Janssens se deve ao alto grau de dificuldade que as representações geométricas de pisos, couros trabalhados ou estampas de tapeçarias colocavam aos pintores, por causa das construções de perspectivas que elas exigiam e que valorizavam as obras. Por outro lado, Heidi de Mare nos informa que pisos de pedra eram mais comuns nos prédios públicos. Sua presença nas pinturas de interiores domésticos servia como símbolo de aspiração por riqueza e prestígio, como era também o caso da introdução de instrumentos musicais, tapetes (jamais eram usados no chão como as pinturas mostravam) e armários com as roupas de cama em linho. $\mathrm{O}$ ambiente bem iluminado e a mulher varrendo o chão não estavam ali retratados de forma verídica, apesar do seu realismo. O chão limpo era algo quase impossível de se manter na Amsterdã do século XVII. A limpeza está ressaltada na tela para significar pureza espiritual e moral, representação adequada a um código de comportamento que adentrava o espaço da casa, contrariando qualquer expectativa de privacidade. A casa era pública como o espaço da rua. A presença da luz se deve também à sua capacidade de enfatizar os jogos de perspectiva entre vários planos, dando-lhes maior impressão de profundidade. As casas não eram iluminadas, uma janela alta e estreita ficava na fachada, outra ao fundo, o restante da casa não tinha janela alguma, pois as paredes eram geminadas, e, por fim, as empregadas eram raras. Muitos elementos aparentemente 
aleatórios e contingenciais, na verdade, integravam códigos bem compreendidos na época. A visão teleológica do setecentismo holandês teria se iniciado com a organização do Estado em torno da célula familiar e do espaço doméstico no século XIX. A compra maciça desses quadros pela sociedade norte-americana só fez acelerar a difusão do mito da domesticidade precoce holandesa ${ }^{47}$.

\section{Figura 8}

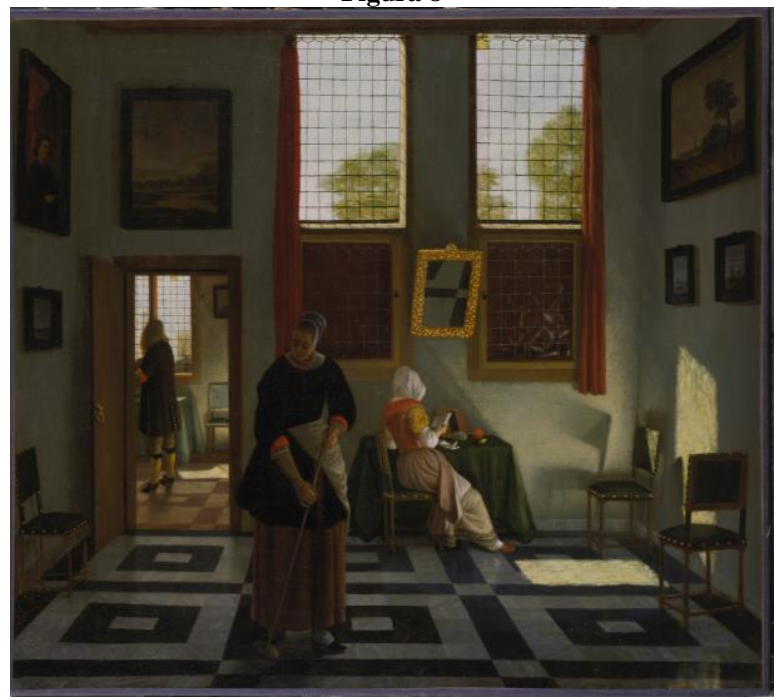

Pieter

Janssens

Elinga,

Interior com

um

Cavalheiro,

uma Mulher

Lendo e uma

Empregada

Óleo em

tela.

c. $1665-70$.

Acervo do

Städel

Museum,

Frankfurt,

Alemanha.

O resultado das abordagens anacrônicas dessa produção foi reduzir a um fenômeno material e concreto - o espaço da casa e seus componentes - o nascimento de sentimentos como privacidade, intimidade, domesticidade e individualidade. Nesta perspectiva, o passado tornou-se um lugar muito próximo ao nosso. E desse uso anacrônico do passado e da casa floresceu outro sentimento típico da vida burguesa - a nostalgia, a saudade de algo que nunca tivemos,

47 MARE, Heidi de. Domesticity in Dispute: a Reconsideration of Sources. In: Irene Cierrad. At Home: an Anthropology of Domestic Space. Syracuse University Press, 1999, p. 13-30; AYNSLEY, Jeremy e GRANT, Charlotte (ed.). Imagined Interiors: representing the domestic interior since the renaissance. London: V\&A Publications, 2006, p. 92-5. 
estado de devaneio alimentado por um sentimento de que algo foi perdido nesse longo processo de nos tornarmos o que hoje somos.

\section{Disney e nostalgia}

O processo de identificação do interior concreto da casa ao interior psíquico de seus habitantes e, a partir daí, sua naturalização, ajuda-nos a compreender as relações dos desenhos animados produzidos por Walt Disney, Branca de Neve e os Sete Anões $(1937)^{48}$ e Cinderela $(1950)^{49}$, com a constituição do repertório setecentista do rococó francês. Desde então, o passado deixara de ser um território inóspito, ao contrário, tornara-se um território explorado, inclusive comercialmente, para o fomento da nostalgia e, com ela, da prática do devaneio ${ }^{50}$ e da fantasia, que se tornara um

48 Na versão Disney, o desenho animado Branca de Neve e os Sete Anões conta a história de uma princesa odiada pela rainha-madrasta por ser considerada pelo espelho mágico a mais bonita de todas as mulheres. A rainha, com inveja, pede ao caçador do palácio o coração da menina. Este, sem coragem para matar Branca de Neve, deixa que ela fuja floresta adentro. Ajudada pelos animais, Branca de Neve encontra a choupana dos sete anões, que a recebem em sua casa. No entanto, a rainha, transformada em uma velha bruxa, oferece uma maçã envenenada a Branca de Neve que, ao mordê-la, morre. Os anões colocam seu corpo em um esquife de vidro no meio da floresta. No entanto, o príncipe, com quem Branca de Neve sempre sonhara, vê a menina-moça e a beija, trazendo-a de volta à vida. Daqui em diante, passarei a me referir ao título de forma abreviada, como Branca de Neve.

$49 \mathrm{Na}$ versão Disney, Cinderela, moça rica, perde o pai amoroso e é reduzida a empregada de sua madrasta e de suas duas filhas. Ela passa a vida sendo maltratada, cuidando da casa e sonhando que seria resgatada por um homem que a amasse de verdade. Certo dia, o príncipe da região convida todas as moças a comparecer ao baile em que ele escolherá sua futura esposa. Ajudada pelos animais e pela fada madrinha, Cinderela consegue ir ao baile e conquista o amor do príncipe. No entanto, vestido e carruagem só durariam até a meia noite. Ao fugir de seu recémamado, Cinderela perde um dos sapatinhos de cristal e é por meio dele que o príncipe descobre sua futura princesa.

50 Segundo Colin Campbell, o devaneio antecipa uma realidade, criando expectativas e consequentemente ansiedade, considerado por ele a componente chave do hedonismo moderno. "[...] a procura do prazer é uma atividade essencialmente motivada pelo desejo de contato com uma dada fonte de prazer. O que acontece, na sua forma moderna, é que o processo de devaneio intervém entre a formulação de um desejo e sua consumação. Consequentemente, os modos de desejar e sonhar se fundem, com um elemento de sonho entrando no próprio desejo." CAMPBELL, Colin. A Ética Romântica e o Espírito do Consumismo Moderno. Rio de Janeiro: Rocco, 2001, p.125. 
elemento estruturante da sociedade de consumo. O espaço "interior" adentrou o terreno infinito da psique, multiplicou-se nos espaços materiais da casa, nas imagens difundidas pela mídia e expandiu-se para o passado. Colin Campbell ${ }^{51}$ buscou compreender o romantismo e suas ligações com a cultura do consumo da mesma forma que Max Weber compreendeu o protestantismo, ou seja, como um modo de pensar fundamental para a constituição do capitalismo moderno. Para Campbell, a capacidade de devanear e sonhar, que se tornou crescente a partir da leitura e do romance moderno, teria se tornado parte indispensável do mecanismo de renovação do ato de consumo. A projeção idealizada de algo que se quer adquirir seria sempre superior (em termos de satisfação) à experiência de realização da aquisição. $\mathrm{O}$ consumidor passaria, então, de uma situação de prazer imaginado ${ }^{52}$ para uma experiência concreta de frustração, já que a realidade ficaria cronicamente comprometida frente ao seu equivalente previamente imaginado (e vivido como fantasia). Insatisfeito, o consumidor se lançaria em um novo projeto de consumo e, assim, sucessivamente, como um sistema em moto-contínuo, o mesmo que caracteriza qualquer moda.

A reapropriação de elementos nostálgicos do passado recursos de representação estética, suas temáticas e narrativas permitiram a atualização de valores contemporâneos, reapresentados com pequenas variações como é o caso dos filmes com princesas da produção Disney. Lançando mão de repertórios ricos e diversificados, Walt Disney logrou adiar a insatisfação de seus consumidores associando os filmes a novos produtos e a inovações tecnológicas na reapresentação de suas narrativas, estratégias aplicadas desde o final da década de 1928, com a criação do personagem Mickey Mouse.

A arquitetura atemporal e fictícia dos dois desenhos, Branca de Neve e os Sete Anões e Cinderela, ergueu-se sobre as heranças iconográficas da literatura, das artes plásticas e do cinema. Se os elementos dos séculos XIX e XX são os mais evidentes e frequentes, podemos encontrar também várias ligações com o repertório e os temas próprios das fêtes galantes. O hibridismo estilístico, em que se 
misturam magia, terror, aventura e romance, excitava a imaginação de seus espectadores. Em paralelo, o mundo fantástico constituído por técnicas e estéticas inovadoras sustentou-se das práticas e valores contemporâneos, especialmente aqueles ligados à vida doméstica das heroínas femininas. A cena em que Branca de Neve orquestra pássaros e pequenos animais na limpeza da choupana dos sete anões é emblemática. O trabalho sincronizado de arrumação da casa refere-se à liderança da dona de casa nos afazeres domésticos, aos modernos eletrodomésticos projetados para serem entendidos como acessórios femininos e, por fim, ao trabalho racional da linha de produção fordista $^{53}$. O encanto da cena está justamente na atemporalidade a que reduzimos o interior doméstico e a vida psíquica. É com base nesta equivalência e naturalização que se constituem também os mundos opostos do bem e do mal. A rainha, quando transformada em bruxa, habita as profundezas do castelo, um espaço que é o prolongamento de sua mente maléfica. Corvos, caveiras, teias de aranha, escuridão e ruínas estão em oposição a coelhos, veados, esquilos, corujas e outros pequenos pássaros que cercam Branca de Neve, em meio a uma natureza florida, colorida e iluminada, como é o espírito da princesa. Projeção de sua bondade, Branca de Neve coloca seus atributos à disposição da vida doméstica dos sete anões.

O desenho Branca de Neve e os Sete Anões ofereceu aos cinéfilos a versão de uma história já conhecida, divulgada no seio de uma longa tradição de contos de fadas, encenada no teatro e mesmo no cinema. O próprio Walt Disney conta que a ouvira inúmeras vezes de sua avó, nas versões de Grimm e Andersen, e que assistira ao filme estrelado por Marguerite Clark e dirigido por J. Searle Dawly, em 1916, espremido entre 16 mil outros garotos em uma sessão com projeção em quatro telas no imenso teatro do Kansas City Convention Centre $^{54}$. No entanto, Walt Disney associou à narrativa já conhecida uma sucessão de empreendimentos inovadores na área do desenho de animação. Branca de Neve e os Sete Anões, lançado em 1937, um

53 WHITLEY, David. The Idea of Nature in Disney Animation. London: New York: Routledge, 2008, p.30-1.

$54 \mathrm{O}$ teatro tinha 12 mil lugares. ALLAN, Robin. Walt Disney and Europe. European Influences on the Animated Feature Films of Walt Disney. London: John Libbey \& Company Ltd, 1999, p. 36-7. 
pouco antes do Natal, é o primeiro desenho animado longa metragem, até então somente curtas tinham sido feitos. O longa incorporava inovações anteriores. Em 1928, Disney lançou o primeiro desenho com som sincronizado à imagem, Steamboat Willie, o terceiro da série com o personagem Mickey ${ }^{55}$. Disney garantiu em 1932 um contrato de dois anos com a Technicolor e com isso produziu também o primeiro desenho animado colorido, Flowers and Trees ${ }^{56}$.

A cena de abertura do desenho Branca de Neve e os Sete Anões é uma sequência que se inicia na floresta em direção ao castelo da rainha má, em um longo travelling o espectador adentra a janela até encontrar o espelho mágico. A sequência foi filmada em um cenário mais longo do que o usual, necessário para o uso de uma câmera multiplanos. Os planos eram decompostos em chapas de vidro pintadas com elementos da cena, o que garantia uma visão de profundidade ${ }^{57}$. Para não cansar a audiência com cores brilhantes, o longa metragem foi feito com uma palheta suave ${ }^{58}$, os cenários de fundo eram pintados com guache, para não criar reflexos, o que ressaltava os personagens, pintados com cores mais fortes. $\mathrm{O}$ trabalho começou a ser produzido em 1934. No ano seguinte, Disney viajou à Europa e fez uma compra de 350 livros ilustrados sobre contos de fadas, fábulas e arquitetura. Foi este o núcleo inicial de uma biblioteca de trabalho que daria apoio aos artistas envolvidos na produção do desenho. À época, a produtora contratou artistas saídos das escolas de arte, de universidades e imigrantes europeus experientes vindos da Hungria, Alemanha, Suécia, Dinamarca, entre outros.

A associação do desenho com a música também era inusitada. $\mathrm{O}$ gosto pelos musicais estaria associado à recente sincronização da imagem com o som (1925) e, com isso, o anseio dos produtores em utilizar a música como parte do entretenimento. A

55 Op. cit., p. 6.

56 Op. cit., p. 7

57 GIRVEAU, Bruno. The Nostalgic Builder: Walt Disney, Architecture and Design. In: RÉUNION des Musées Nationaux; MONTREAL Museum of Fine Arts. Once Upon a Time. Walt Disney. The Sources of Inspiration for the Disney Studios. Once Upon a Time. Berlin: Prestel, 2007 p. 210.

58 ALLAN, Robin. Walt Disney and Europe. European Influences on the Animated Feature Films of Walt Disney. London: John Libbey \& Company Ltd, 1999, p. 47. 
série Silly Symphonies procurava difundir a música associada ao humor, ideia do diretor musical Carl Stalling. Branca de Neve e os Sete Anões exigiu mais de um milhão de desenhos. Antes da invenção do processo Xerox (1959), que permitiria a transferência mecânica do desenho em papel para o celuloide transparente, os desenhos, após ser concebidos pelos animadores, eram limpos por assistentes e enviados para o Departamento de Desenho e Pintura. Nele os desenhos eram copiados manualmente em celuloide e pintados com até cinco cores. O celuloide era então fotografado sobre o cenário de fundo.

A produtora funcionava como uma linha de produção em que cada departamento não ficava a par do que o outro fazia. Os oligopólios das companhias cinematográficas norte-americanas (Metro-Goldwyn-Meyer, Paramount Pictures), que conheceram seu auge nos anos de 1920, controlavam verticalmente a produção e distribuição de seus filmes e Walt Disney conheceu várias falências antes de encontrar um modo de sobreviver. A Disney Company conseguiu se manter por meio do copyright de seus desenhos. Diferentemente dos estúdios europeus, a Disney adotava uma postura antiartística para as suas obras, realizadas em um esquema de produção com forte divisão de trabalho, os produtos da empresa eram considerados obras coletivamente produzidas para o entretenimento. A estrutura de produção era fortemente centralizada no produtor e não no diretor, como acontecera no cinema europeu ${ }^{59}$. Um ano após o lançamento de Branca de Neve, a Disney tinha 1.200 funcionários $^{60}$.

O Departamento de Desenho e Pintura era formado exclusivamente por mulheres, que, ao aplicar as cores nos personagens também maquiavam as personagens femininas. Branca de Neve recebia sombra acinzentada sobre as pálpebras, batom nos lábios e ruge nas maçãs do rosto, este na forma circular (Figura 9), exatamente como faziam as mulheres aristocratas francesas do setecentos, como observamos no retrato de Madame LouiseElisabeth, duquesa de Parma, de Jean-Marc Nattier (Figura 10). Para

59 BOHAS, Alexandre. The Political Economy of Disney. The Cultural Capitalism of Hollywood. London: Macmillan Publishers, 2016, p.15-32.

60 ALLAN, Robin. Walt Disney and Europe. European Influences on the Animated Feature Films of Walt Disney. London: John Libbey \& Company Ltd, 1999, p.36. 
ambas, a maquiagem é explícita, sinal de linhagem e juventude, ou vontade de se manter jovem, como no caso da rainha e de Madame Marsollier. Ambas se defrontam com o espelho, oráculo que prenuncia o envelhecimento e a perda da beleza (figura 11). Tema que se vulgarizou, alcançando inclusive as porcelanas da manufatura gaúcha Rebis ${ }^{61}$ (Figura 12). No retrato de Madame Marsollier com sua filha, a inveja é substituída pela sutil tensão entre as belezas madura e púbere de $\mathrm{m}$, em que a mais velha, a mãe, ensina os segredos de toalete para a mais jovem, sua filha, ainda inexperiente ${ }^{62}$ (Figura 5).

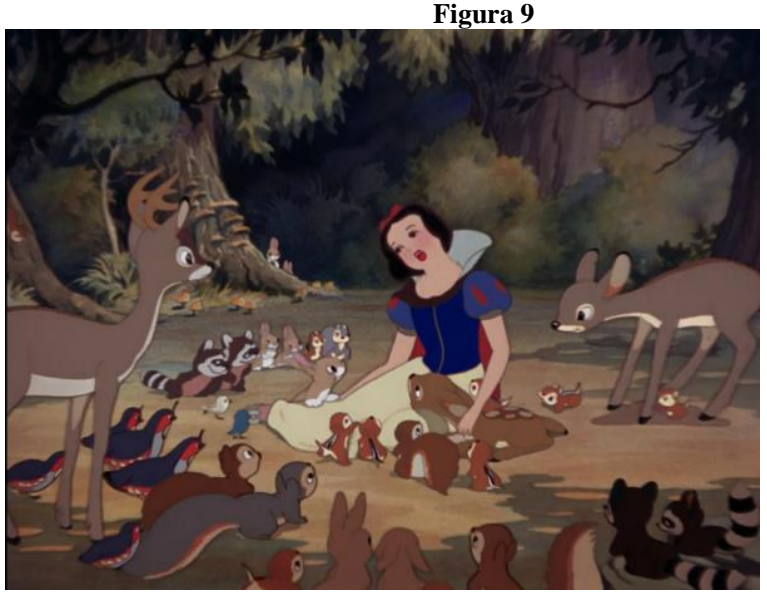

Cena do

desenho animado longa metragem Branca de Neve e os Sete Anões, em que a heroína acorda na floresta e é surpreendida pelos animais. Copyright Disney Enterprises, Inc.

61 Os modelos da Rebis foram feitos a partir de cópias modificadas de peças em porcelana trazidas de outra empresa produtora de scènes de courtoisie, a Renner, também gaúcha. A fábrica funcionou entre 1956 e 2013. O alemão Anton Steiner deixou a Renner, onde trabalhava como artesão, para abrir seu próprio negócio com dois outros sócios, o polonês Josef Bilan e o iugoslavo Ivo Res. Logo em seguida, um quarto sócio, brasileiro, filho de imigrantes poloneses, Sergio Skopinski, foi convidado a ingressar na empresa a fim de cuidar de sua administração e contabilidade. Sem conhecimento prévio sobre a produção das "estatuetas", Sergio se tornaria em pouco tempo o único proprietário da empresa e a manteria ativa por 57 anos. Se já nos causava espanto o surgimento de uma fábrica de bibelôs inspirados na iconografia galante em plena década de 1950, no Brasil, o que pensar do fato de que a produção conheceu seu ápice nos anos de 1980? A fábrica chegou a ter 35 funcionárias neste período. Eram só mulheres, sem experiência com qualquer tipo de trabalho com porcelana. Com suas habilidades em costura e nas atividades de dona-de-casa produziram centenas de milhares de esculturas.

62 Chrisman-Campbell, op. cit. p. 67. 


\section{Figura 10}

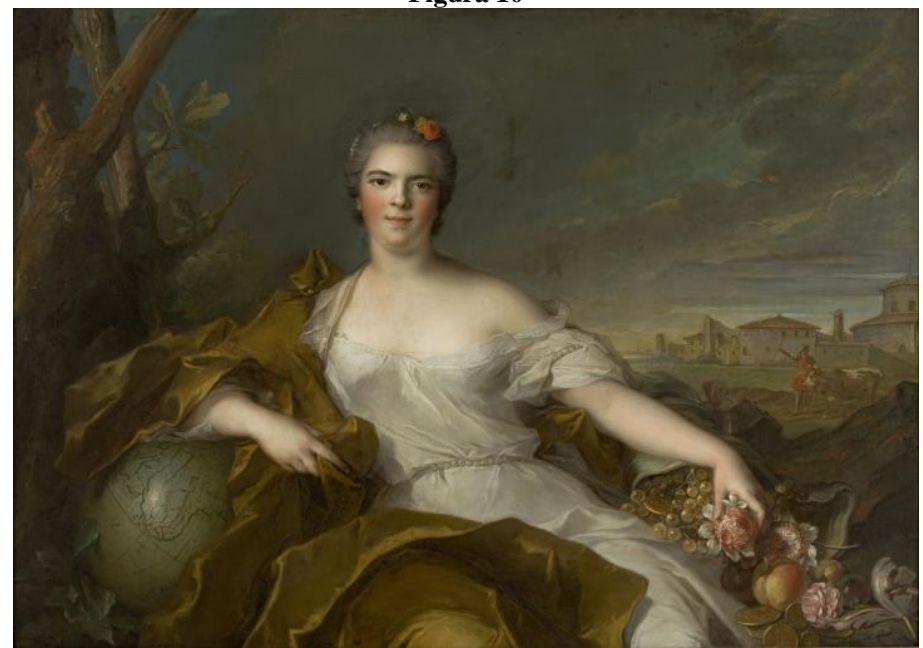

Madame Louise-Elisabeth, duquesa de Parma - A terra, óleo sobre tela de autoria de Jean-Marc Nattier, 97 x 136 cm, Paris, 1750. Foto de João Musa. Acervo do Museu de Arte de São Paulo Assis Chateaubriand, São Paulo.

\section{Figura 11}

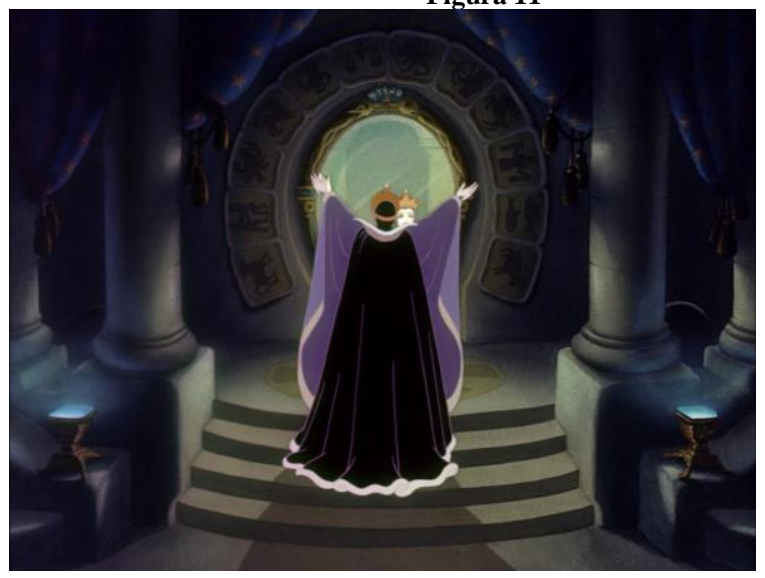

Cena do desenho animado longa metragem Branca de Neve e os Sete Anões, em que a rainha consulta o espelho mágico para saber quem é a mulher mais bela do reino. Copyright Disney Enterprises, Inc. 
Figura 12

Antonieta, porcelana, $17 \mathrm{~cm}$, artesão Anton Steiner, Rebis, Porto Alegre, RS, 1956. Acervo do Museu Paulista da Universidade de São Paulo.

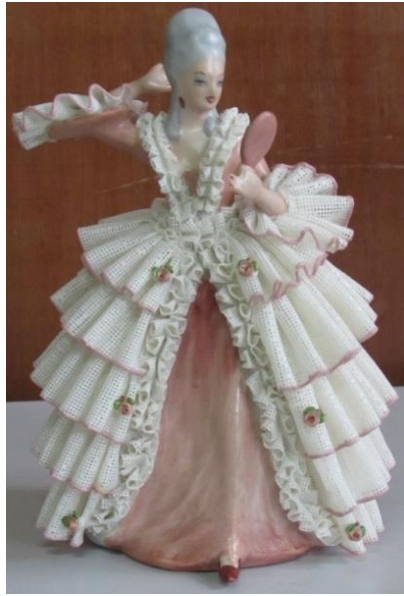

O momento da toalete feminina, como vimos, era uma maneira da mulher aristocrata setecentista se transformar durante o dia. A cobertura da pele e dos cabelos com pomada e pó branco, a aplicação do vermelho no rosto, o corpo vestido com camadas de saias para ampliar o volume do quadril e fazê-lo contrastar com a estreita cintura moldada pelo espartilho ${ }^{63}$ e os seios altos, que aquele possibilitava, a cobertura final com tecidos luxuosos, finamente bordados, e as joias, tudo fazia parte desse ritual de transformação. Nos desenhos Branca de Neve e Cinderela o gosto pela transformação está igualmente presente. A rainha se transforma em bruxa, a casa suja dos anões se transforma no mais aconchegante dos lares, a Cinderela se transforma em dama requintada, a abóbora em carruagem, os ratos em cavalos, o pangaré em libré. Nos anos de 1930 estavam nas telas norte-americanas os filmes de terror que tinham também cenas de transformação como Drácula (versão com o ator Bela Lugosi, 1931), Werewolf of London (com Wilfred Glendon,

63 MILLER, Leslie Shannon. "The Many Figures of Eve: Styles of Womanhood Embodied in a Late-Nineteenth-Century Corset". In: PROWN, Jules David \& HALTMAN, Kenneth. American Artifacts. Essays in Material Culture. East Lansing/Michigan, Michigan State University Press, 2000, pp. 71-92. 
1935), The Devil Doll e Dr. Jekyll and Mr. Hyde (versão com o ator Fredric March, 1931), conhecido no Brasil como O Médico e o Monstro.

A Madame Louise-Elisabeth, duquesa de Parma, retratada por Nattier com vestes e símbolos alegóricos, leva na mão esquerda flores e frutas saídas de uma cesta em forma de cornucópia. A heroína Branca de Neve aparece cercada de flores em vários momentos do longa metragem. Tais representações, que se tornaram comuns durante todo o século XIX, e que podem ser fartamente encontradas em retratos fotográficos, acessórios e estampas de tecidos, nos conselhos de manuais de etiqueta, sugerem uma afinidade culturalmente entendida como intrínseca entre o feminino e a natureza artisticamente representada $^{64}$. Já mencionamos a presença da natureza idealizada nas pinturas e esculturas do rococó. Estas imagens chegaram ao século XX como itens de decoração dos ambientes domésticos da classe média urbana, já consolidados como repertório feminino (Figura 13). Os recursos dramáticos na representação da natureza, presentes nas ilustrações do século XIX, fontes de inspiração de Branca de Neve, com troncos e galhos retorcidos, deformações próprias da releitura de elementos góticos, que ofertavam às cenas uma conotação sutilmente sombria, não desvincularam a figura feminina dos elementos naturais, como podemos observar na gravura de Richter, em ilustração da mesma personagem - uma Branca de Neve com cabelos loiros, longos, cercada por veados, pássaros, emoldurada por galhos de árvores, tendo em sua base dois anões, claramente apresentados como seres ligados à terra (Figura 14). Em Disney, a natureza construída com os traços deformadores dos gravuristas românticos é mobilizada para os momentos de ameaça. Em oposição estão as representações de uma natureza luminosa e amigável, esta sim identificada à personagem Branca de Neve e referente ao ideal de harmonia presente nas fêtes galantes.

64 CARVALHO, Vânia Carneiro de. Gênero e artefato. O sistema doméstico na perspectiva da cultura material. São Paulo: EDUSP/Fapesp, 2008, p. 247-271. 


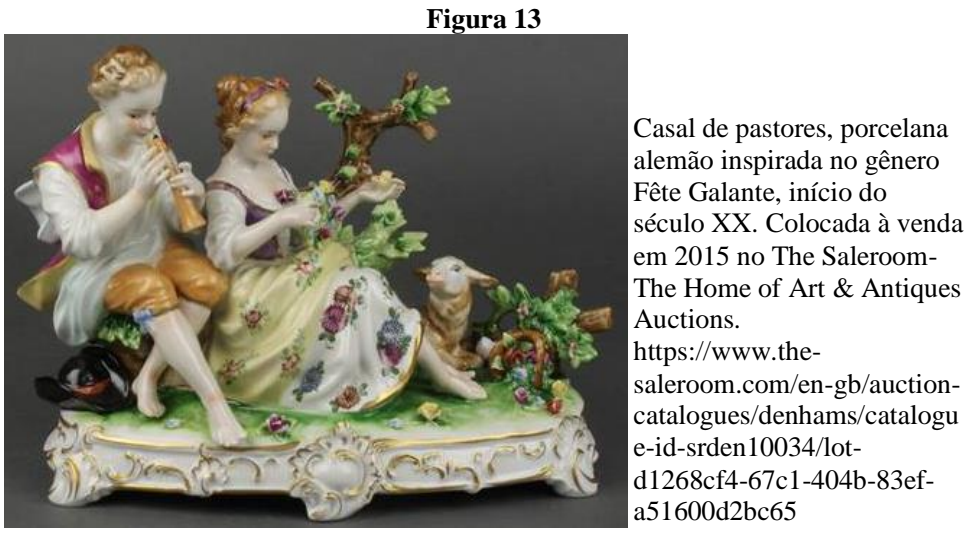

Figura 14

Branca de Neve, gravura a partir de desenho de Adrien Ludwig Richter, $21 \times 12 \mathrm{~cm}$, Berlim, séc. XIX, Nationalgalerie.. Fonte: Source: http://www.zeno.org Contumax GmbH \& Co.

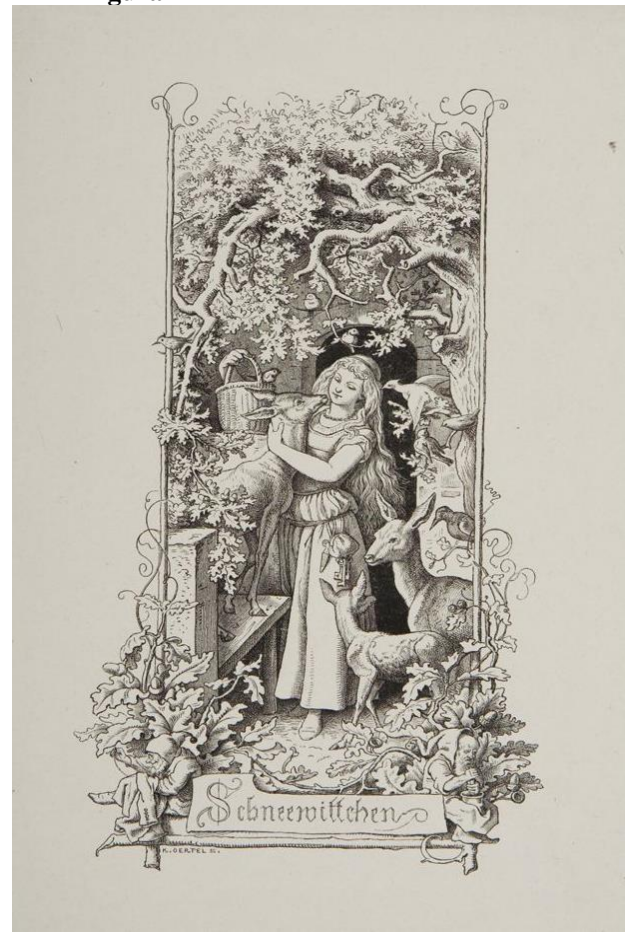


As cenas de cortesia passaram por mudanças que se consolidaram no século XIX. As imagens de grupos de aristocratas engajados em atividades de socialização tornaram-se rarefeitas, dando-se preferência à representação de casais. A estética e temática das fêtes galantes foram confrontadas com os ideais românticos do oitocentos, fartamente presentes na literatura e no teatro, e que se caracterizaram pela busca de uma simplicidade idealizada do medievo, uma nostalgia pelo meio rural em oposição às cidades e pelo amor entre os casais. Romeu e Julieta de Shakespeare é uma das matrizes mais próximas de Branca de Neve. Buscou-se em um passado distante a legitimação do amor, do casal branco e heterossexual, valores presentes na produção de Disney e já fartamente explorados pela literatura acadêmica ${ }^{65}$. Não foi por acaso que a Rebis lançou a escultura Debutantes, em 1956. Nela, dois jovens ingressando na vida adulta simulam o momento de convite para a dança (figura 15).

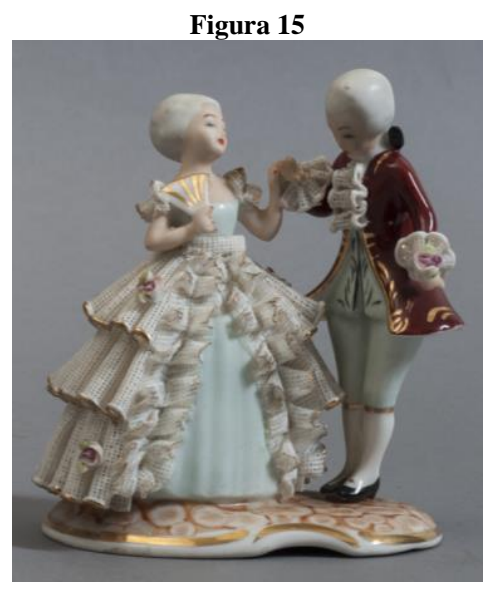

Debutantes, porcelana, $9,5 \times 6,5 \times 11,0$ $\mathrm{cm}$, Indústria e Comércio de Porcelana Rebis, Porto Alegre, a partir de 1956. Fotografia de José Rosael. Acervo Museu Paulista da Universidade de São Paulo.

Em Branca de Neve e os Sete Anões reconhecemos a associação dos valores de feminilidade doméstica à mulher contemporânea. Seu vestido é uma criação dos desenhistas de Disney que combina inspirações 
do século XVI - capa, colarinho alto e mangas bufantes com aberturas em linhas longitudinais para mostrar outro tecido em cor diferente - com o corpete acinturado usado intensamente no século XIX. Uma versão mais próxima das mangas renascentistas pode ser vista na interpretação romântica do ilustrador Carl Offterdinger (Figura 16). Os cabelos e traços de Branca de Neve foram inspirados nas imagens familiares e prestigiosas de atrizes do cinema dos anos de 1920 e 1930, como as estrelas do cinema mudo Janet Gaynor e Mary Pickford e a menina Shirley Temple. Da personagem de desenho Betty Boop, que chegou a ser censurada por causa de sua sensualidade, Disney retirou o formato dos olhos para as expressões de espanto e medo de Branca de Neve ${ }^{66}$ (Figuras 17-20). O laço nos cabelos de Temple está também nos cabelos da heroína. Esta transposição nos ajuda a lembrar que Branca de Neve representa uma menina de 14 anos, como determinou explicitamente Walt Disney em memorando que orientava seus desenhistas ${ }^{67}$.

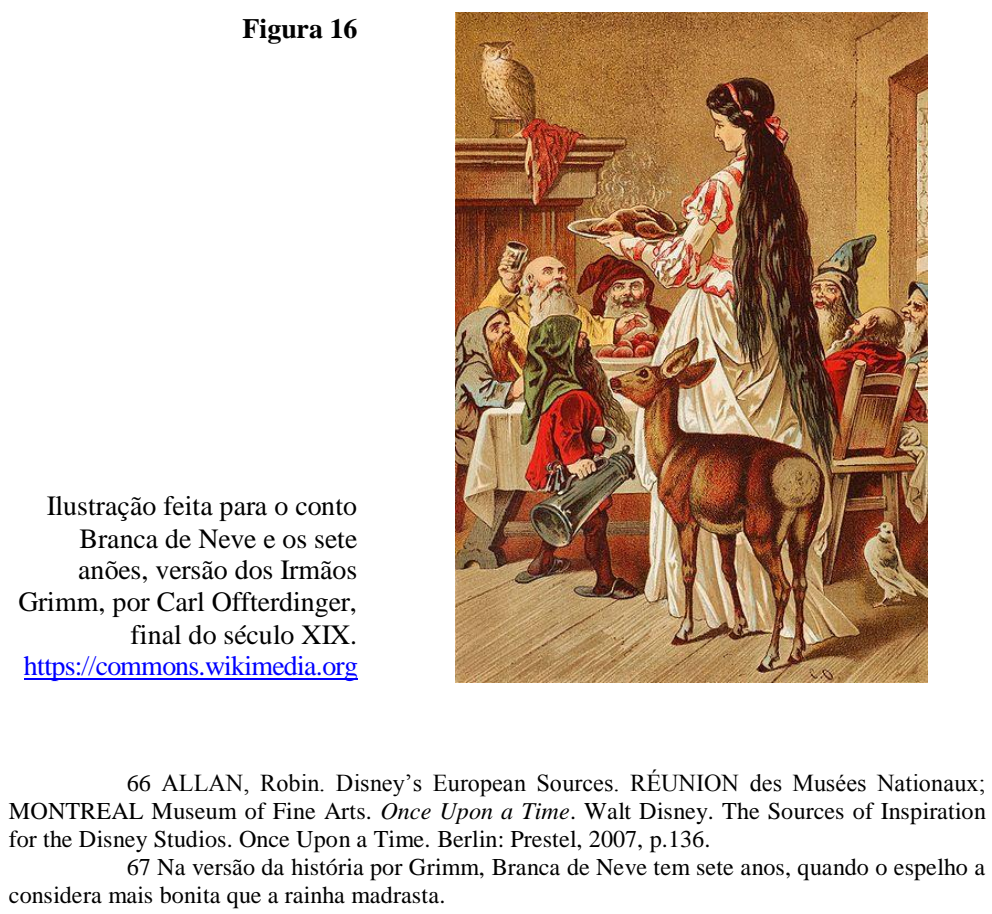




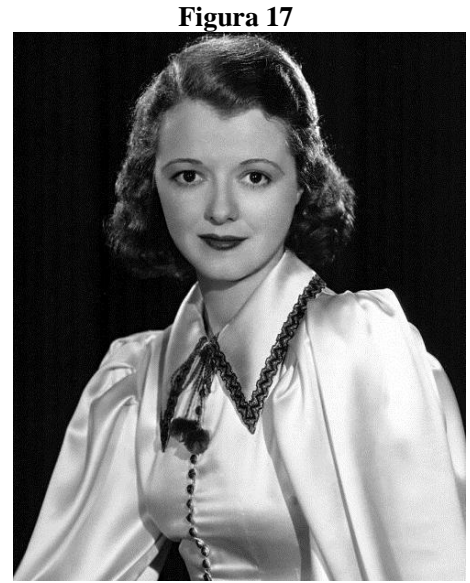

Janet Gaynor, 1934, fotografia publicitária do filme Servant's Entrance https://commons.wikimedia.org/wiki/Fi le:Janet Gaynor-

publicity.JPG?uselang=pt-br

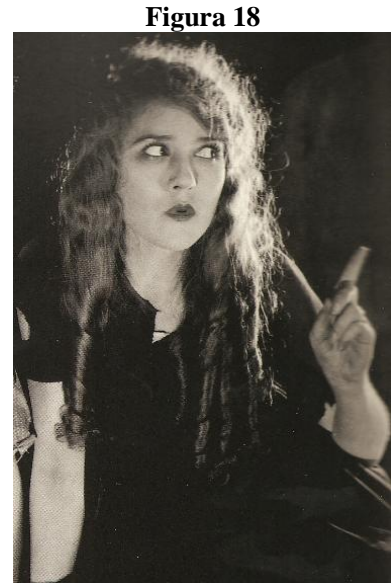

Mary Pickford, no filme A Little Princess, dirigido por Marshall Neilan com roteiro de Francis Marion, 1917. https://commons.wikimedia.org/wiki/Fil e:Mary Pickford in The Little Princes s.png

Figura 19

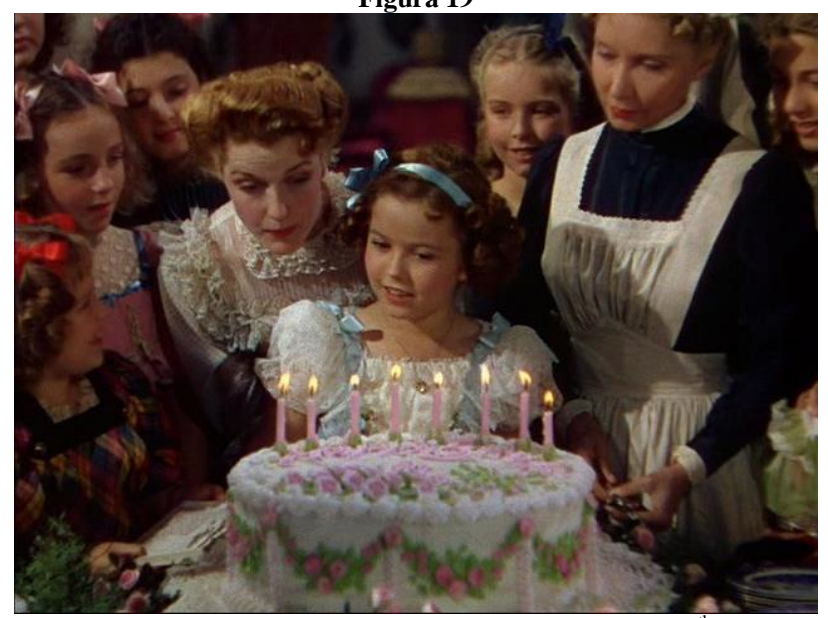

Shirley Temple, The Little Princess, dirigido por Walter Lang, $20^{\text {th }}$ Century Fox, 1939. https://commons.wikimedia.org/wiki/File:Little_Princess_4.JPG 
Figura 20

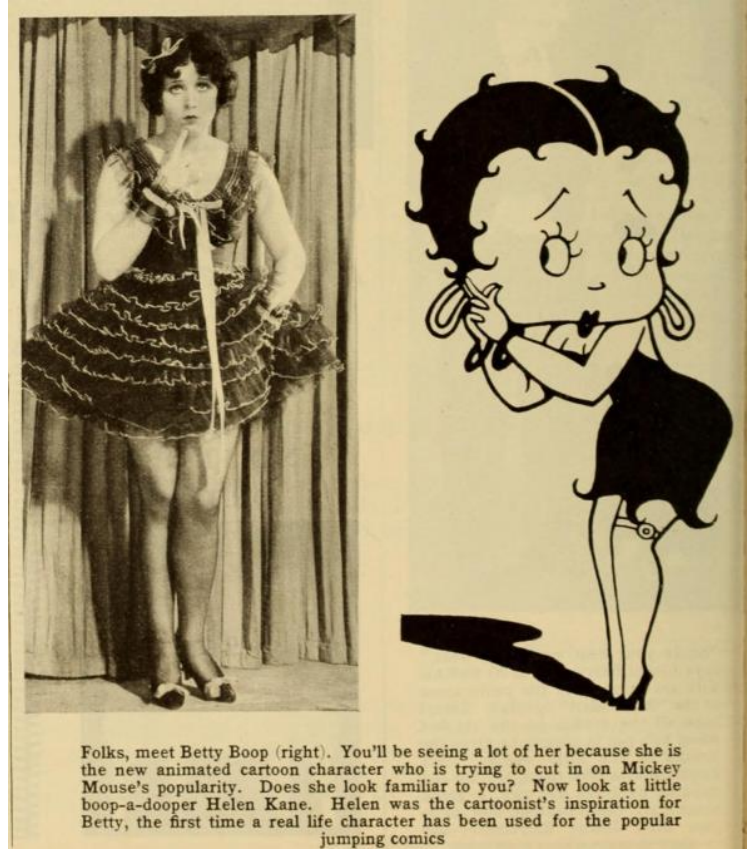

Betty Boop, criada por Max Fleischer e desenhada por Grim Natwick, produzida pelo Fleischer Studios e distribuída pela Paramount Pictures, sua primeira aparição foi em 1930. Os olhos da personagem são parecidos com os da atriz e dançarina Helen Kane e os de Branca de Neve na versão Disney. https://en.wikipedia.org/wiki/Helen_Kane\#/media/File:Helen_Kane_and_Betty_Bo op - Photoplay, April 1932.jpg

Nos anos de 1930, a audiência do cinema norte americano era predominantemente de mulheres. No entanto, não havia estratificações etárias, tendo sido Branca de Neve concebido para adultos e crianças. Várias cenas, especialmente a noite na floresta, com árvores metamorfoseadas em monstros inspirados nas ilustrações de Gustave Doré, e a transformação da rainha em bruxa, apavoraram as crianças à época do lançamento do desenho. As cenas de medo, maldade e perigo tinham uma plasticidade advinda do cinema 
expressionista alemão e da tradição gótica e grotesca dos livros ilustrados do século $\mathrm{XIX}^{68}$. Sua força levou a Inglaterra, depois da Segunda Guerra, quando essa produção se voltou especialmente aos jovens, a cortar algumas cenas do desenho. A densidade do desenho não se restringia aos recursos estéticos, mas advinha igualmente da estrutura narrativa. Apesar de menina, ou justamente por isso, a primeira princesa da dinastia Disney era uma figura complexa e ambígua, características que desaparecerão em Cinderela. Branca de Neve era uma menina com desejos de mulher; ela sonhava em ter contato amoroso com um homem, o príncipe; vivia com sete homens na floresta, os anões, que ela tratava como crianças, cumprindo, assim, o papel de mãe e por extensão de dona-de-casa. A jornada da princesa se precipita quando sua beleza ameaça a rainha-madrasta. Sua aventura na floresta pode ser comparada a um rito de passagem da vida infantil para a adulta. Branca de Neve morre e ressuscita para uma nova vida, longe de seus amigos de infância. "Ela tem anseios românticos. Magicamente, ela sobrevive à morte. Ela oferece um elixir ao público - um coração puro e um desejo intenso podem construir um amor que transcenda a estase e a dor"69.

Walt Disney queria dotar a heroína Branca de Neve de uma beleza e inocência dramáticas, atributos incompatíveis com os traços cômicos e caricaturais presentes em animais e plantas antropomorfizados, marcas do desenho animado. A primeira experiência que buscou uma solução gráfica para a personagem foi feita com The Goddess of Spring (Deusa da Primavera), um dos curtas da série Silly Symphony, realizado em 1934, que buscou construir a figura feminina com base na tradição alegórica. O uso da alegoria é mais uma aproximação possível entre as representações do setecentos francês e o repertório imagético desenvolvido por Walt Disney. Em um dos desenhos curta metragem da série Silly

68 GIRVEAU, Bruno. Beyond the Mirror: Walt Disney and Literature and Cinema. In: RÉUNION des Musées Nationaux; MONTREAL Museum of Fine Arts. Once Upon a Time. Walt Disney. The Sources of Inspiration for the Disney Studios. Once Upon a Time. Berlin: Prestel, 2007, p.172-206.

69 "She has romantic yearnings. Magically, she survives death. She offers an elixir to the audience - a pure heart and intense longing can build a love that transcends stasis and pain". ALLAN, Robin. Walt Disney and Europe. European Influences on the Animated Feature Films of Walt Disney. London: John Libbey \& Company Ltd, 1999, p. 62. 
Symphony, Walter Babies (1935) utiliza babies equivalentes aos pucci, querubins ou cupidos presentes nas esculturas do gênero fête galante, que tinham nas alegorias uma importante fonte de inspiração (Figuras 21-23). Estas representações alegóricas de crianças nuas, já presentes no barroco, simbolizavam o amor, a fertilidade e a pureza. Os babies de Disney estavam associados à audiência feminina e sua presença buscava cativar as mulheres, que segundo a intuição de Walt Disney veriam essas criaturas como cute (fofinhas). O uso dos babies foi testado também no longa Branca de Neve. Eles estariam presentes na última cena, depois suprimida, em que o casamento da heroína com o Príncipe apareceria em uma nuvem, com os babies empurrando ou soprando o casal em um barco do amor. Em ambos os desenhos, notamos as significações dessas figuras associadas aos elementos da natureza e à transcendência ${ }^{70}$.

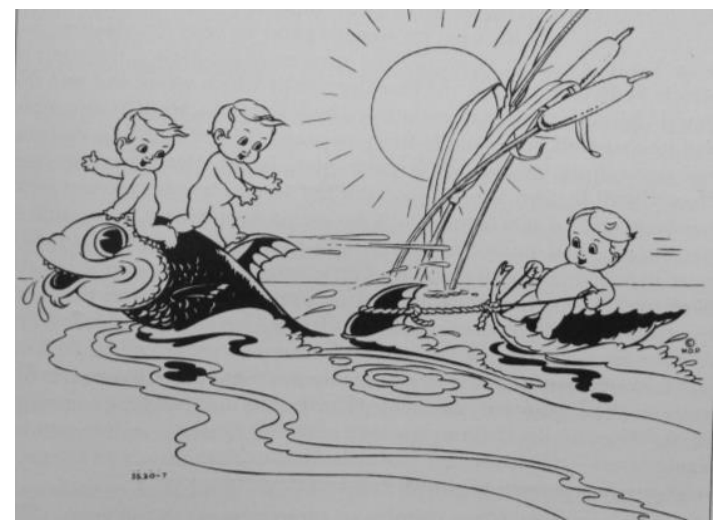

Figura 21

Water Babies, a Silly Symphony, 1935. Copyright Disney Enterprises, Inc.

70 Disney, em um dos desenhos em curta metragem da série Silly Symphony, Walter Babies (1935) utiliza babies equivalentes aos pucci, querubins ou cupidos presentes nas esculturas do gênero fête galante. Estas representações alegóricas de crianças nuas, já presentes no barroco, simbolizavam o amor, a fertilidade, a pureza. Os babies de Disney estavam associados à audiência feminina, sua presença buscava cativar as mulheres, que segundo a intuição de Walt Disney veriam essas criaturas como cute (fofinhas). Apesar da aparente frivolidade na justificativa do uso dos babies, eles foram projetados uma cena, depois suprimida, em que o casamento de Branca de Neve com o Príncipe apareceria em uma nuvem, com os babies empurrando ou soprando o casal em um barco do amor. Em ambos os desenhos, notamos as significações dessas figuras associadas aos elementos da natureza e à transcendência. 
Grupo de querubins, porcelana Meissen, Alemanha. Modelo de 1770, confecção do século XIX.

https://br.pinterest.com /pin/616993217670524495/
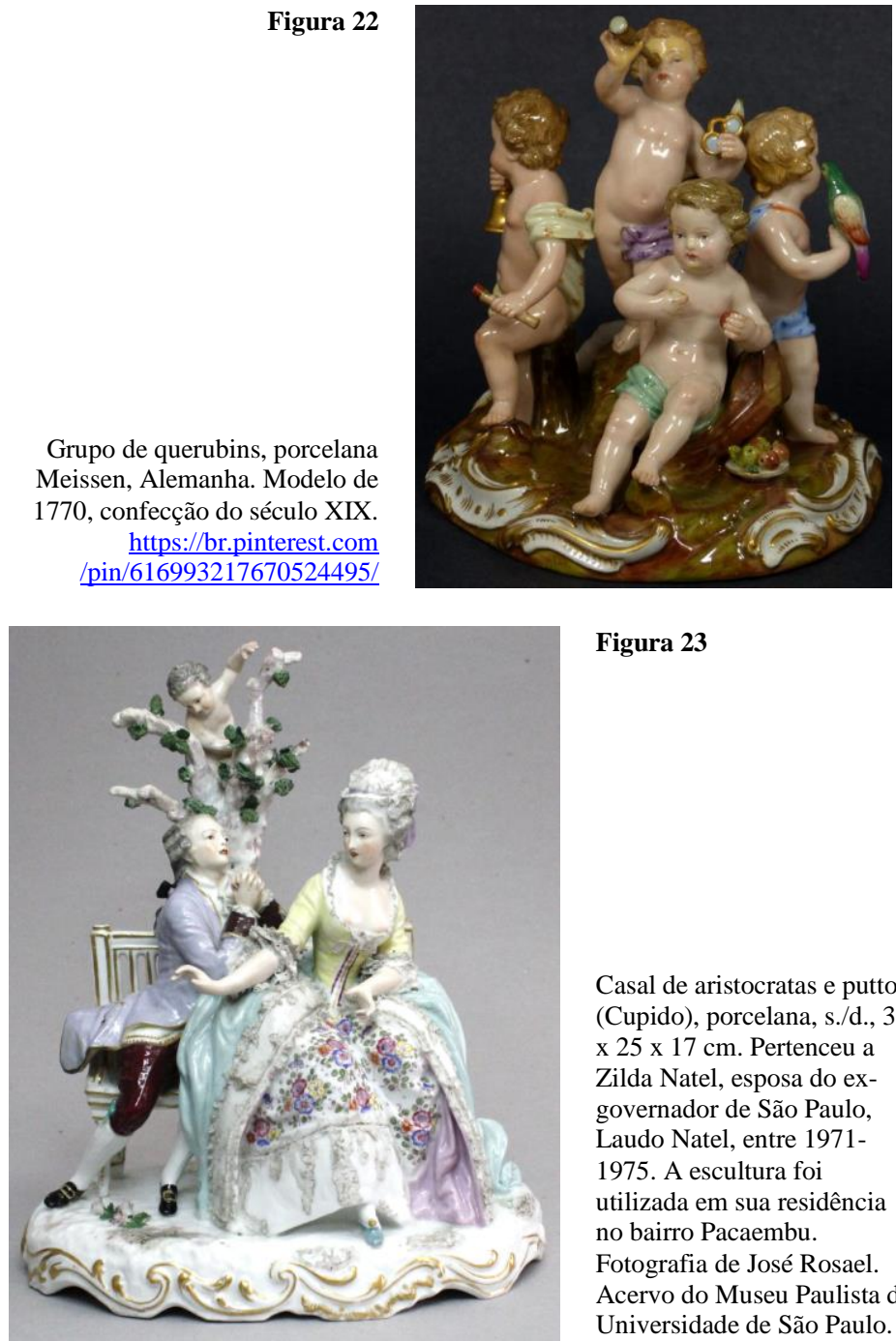

Figura 23

Casal de aristocratas e putto (Cupido), porcelana, s./d., 31 x $25 \times 17 \mathrm{~cm}$. Pertenceu a Zilda Natel, esposa do exgovernador de São Paulo, Laudo Natel, entre 19711975. A escultura foi utilizada em sua residência no bairro Pacaembu. Fotografia de José Rosael. Acervo do Museu Paulista da Universidade de São Paulo. 
Em The Goddess of Spring, a personagem feminina representa Perséfone ${ }^{71}$, uma mulher que deveria ser sublime, tanto pela missão que lhe cabia, fazer a natureza florescer, quanto pela sua força e altivez ao enfrentar o Inferno e o Demônio para conseguir subir à Terra durante a primavera e o verão ${ }^{72}$. Todos os diálogos são cantados na forma de uma opereta. No entanto, o desenho da deusa não parece acompanhar os atributos da personagem. Criticou-se à época, em especial, a aparência excessivamente elástica dos movimentos das pernas e braços, comparados a uma mangueira de borracha. Buscando uma solução para o problema, o desenho da personagem Branca de Neve Disney foi feito inicialmente com sequências ao vivo, que eram filmadas e decompostas em todos os seus movimentos por um equipamento chamado rotoscópio, patenteado em 1917. Cada movimento decomposto era copiado para o desenho, dando mais realismo aos movimentos. As sequências ao vivo foram realizadas pela dançarina e coreógrafa Marge Belcher. A voz de Branca de Neve era de Adriana Caselotti, uma jovem de18 anos, filha de um professor italiano de canto ${ }^{73}$. A junção entre dança e música era um objetivo perseguido pelos criadores do desenho. Os diálogos deveriam conduzir ao canto.

Os movimentos "dançantes" de Branca de Neve nos permitem outra aproximação com as heranças das fêtes galantes. A dança era o modo mais sofisticado de exibição das habilidades sociais da aristocracia francesa do séc. XVIII. Por isso mesmo, ela está presente nas representações de homens e mulheres nas pinturas e esculturas do gênero. A coreografia aristocrática tinha como objetivo construir um ser etéreo, em que espírito e corpo permaneceriam afastados das qualidades terrenas da vida. À metáfora corporal somavam-se roupas e acessórios como sapatos com saltos altos, casacas masculinas com as pontas inferiores voltadas para cima, aerodinâmica que projetava o corpo masculino numa linha ascendente

71 Perséfone é a deusa grega da primavera. Ela foi raptada pelo seu tio, Hades, irmão de seu pai, Zeus, e foi obrigada a viver no mundo inferior. Em seu cativeiro, Perséfone deixou de se alimentar e para impedir sua morte, Hades permitiu que ela voltasse ao convívio dos pais, no Olimpo, uma vez ao ano, quando, com sua presença, a natureza florescia.

72 Na versão de Disney, o irmão de Zeus, Hades, torna-se o Demônio da mitologia cristã.

73 ALLAN, Robin. Walt Disney and Europe. European Influences on the Animated Feature Films of Walt Disney. London: John Libbey \& Company Ltd, 1999, p. 40. 
e vestidos que tinham uma grande circunferência abaixo da cintura e, ao menos em sua parte frontal, não mais arrastavam no chão. O robe à la française, item da moda feminina no século XVIII, dava a impressão de flutuar quando sua usuária caminhava.

Esse modo de ser migrou, no século XIX, para as mulheres, que incorporaram como atributo feminino a exibição das habilidades aristocráticas antes comuns a ambos os sexos. Branca de Neve sintetiza de maneira espetacular o ideal aristocrático do setecentismo transmutado em feminilidade. Seus movimentos se opõem frontalmente aos dos anões e ela desliza como uma bailarina ao longo das treze das vinte cenas que compõem o desenho.

No momento em que Cinderela foi lançado, em 1950, Disney está envolvido com a construção de seu primeiro parque temático (1955) e com a futura abertura de seu programa de televisão (1954). Depois da Segunda Guerra, os grandes estúdios dos anos de 1920 entraram em colapso devido à queda dos lucros, não somente por causa da guerra, mas também devido ao fortalecimento dos sindicatos e à entrada da televisão. Diretores, artistas e produtores saíram das grandes companhias para abrir seus próprios estúdios. A Disney começou a se fortalecer economicamente a partir de 1953, com a criação de uma divisão de distribuição na empresa, que fez o lucro saltar de 500 mil dólares, em 1952, para 3,4 milhões em 1959 e 11 milhões em $1965^{74}$.

Apesar dos lucros que se prenunciavam, já que Cinderela fez mais sucesso que Branca de Neve e os Sete Anões, a empresa havia perdido, a esta altura, os artistas europeus experientes que trabalharam na produção dos curtas e primeiro longa nos anos de 1920 e 1930. O uso extensivo da transposição da filmagem ao vivo, com o objetivo de economizar tempo e dinheiro investido no trabalho artesanal dos animadores, pareceu para muitos ter esvaziado a produção de Cinderela do encanto e criatividade da tradição do desenho. No entanto, os cenários escolhidos para Cinderela eram aqueles do século XVIII, o que deu oportunidade de exploração de ambientes mais luxuosos. O ápice do desenho é a transformação de 
Cinderela em uma dama luxuosa, seu percurso com a carruagem e o momento do baile (Figura 24). Trajando um vestido espartilhado e volumoso, cabelos presos e sapatos de cristal, Cinderela dança com o príncipe, momento que foi retomado com muito mais glamour (mas não tanto sucesso) em 2015, no filme dirigido por Kenneth Branagh. Neste último, a coreografia do casal novamente nos remete ao século XVIII. O vestido azul da atriz Lily James, coberto por centenas de cristais Swarovski, armado, mas leve, criado por Sandy Powell, homenageia a geração que assistiu ao desenho nos anos de 1950. Segundo Powell, "Eu estava fazendo uma versão década de 40 e 50 do século XIX"75. O pós guerra foi a época de uma retomada nostálgica na moda, o new look de Christian Dior. Contrapondo-se aos modelos urbanos de inspiração masculina de Coco Chanel, Dior lançou vestidos mais caros, até mesmo para os padrões da alta costura, que chegavam a consumir 25 metros de tecido. Os vestidos Dior incluíam corsets (herdeiros dos espartilhos), cintas, tule, enchimentos e saias armadas.

Figura 24

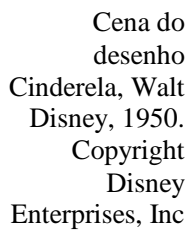

Cena do desenho Cinderela, Walt Disney, 1950.

Copyright

Disney Enterprises, Inc

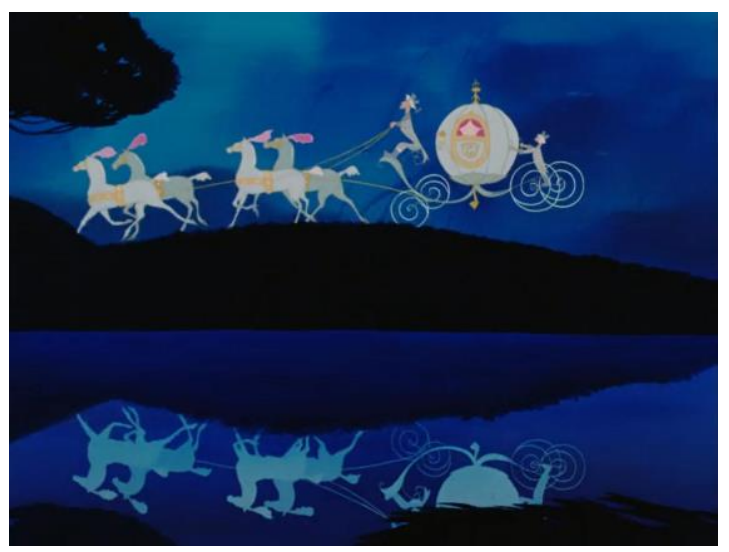

75 "I was kind of doing a 1940s, 1950s version of the nineteenth century". Apesar de ser referir ao século XIX como sua referência, sabemos que o espartilho e o volume das saias deste século foram uma retomada do setecentos. SOLOMON, Charles. A Wish Your Heart Makes. From the Grimm Brothers' Aschenputtel to Disney's Cinderella. New York: Los Angeles: Disney Editions, p. 162-3. 
Desenho e moda atuaram a favor da volta da mulher ao espaço da casa, depois de sua participação no mercado de trabalho durante a Segunda Guerra. As dificuldades econômicas e a ansiedade social provocada pela liberdade que as mulheres conheceram provocaram a produção de artefatos e imagens que se colocaram na contracorrente da liberação feminina. As cenas de cortesia estão inseridas neste circuito conservador, que sonhava com uma mulher glamorosa, porém circunscrita aos limites do lar e dedicada ao marido e filhos. Se as cenas de cortesia forneceram parte do repertório para os desenhos animados e a moda, elas também se alimentaram desse mesmo caldo cultural. Prova disso são as esculturas vintage em porcelana de carruagens (Figuras 25). Uma delas, produzida nos anos de 1960, refere-se à carruagem em que Napoleão I teria percorrido Paris em 1810, após seu segundo casamento; a outra seria a carruagem de "Cinderela", conforme nomeação de seu proprietário (Figura 26).

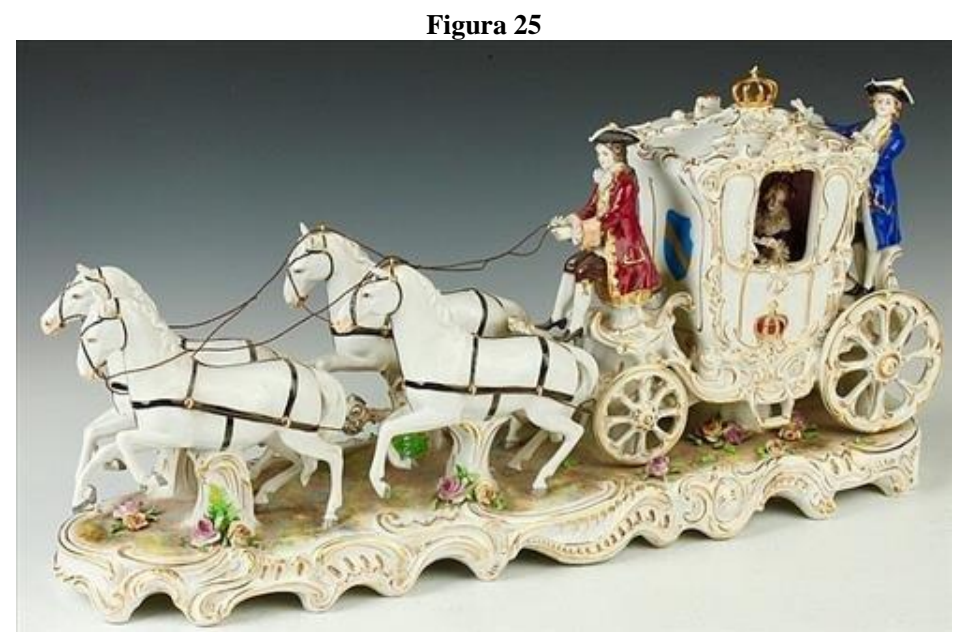

"Carruagem com quatro cavalos", porcelana, Dresden, Alemanha, sem data, oferecida em Liveauctioneers, vendida por US\$1000 em 13 de junho de 2015. https://new.liveauctioneers.com/item/37589731_dresden-porcelain-four-horse-carriage 


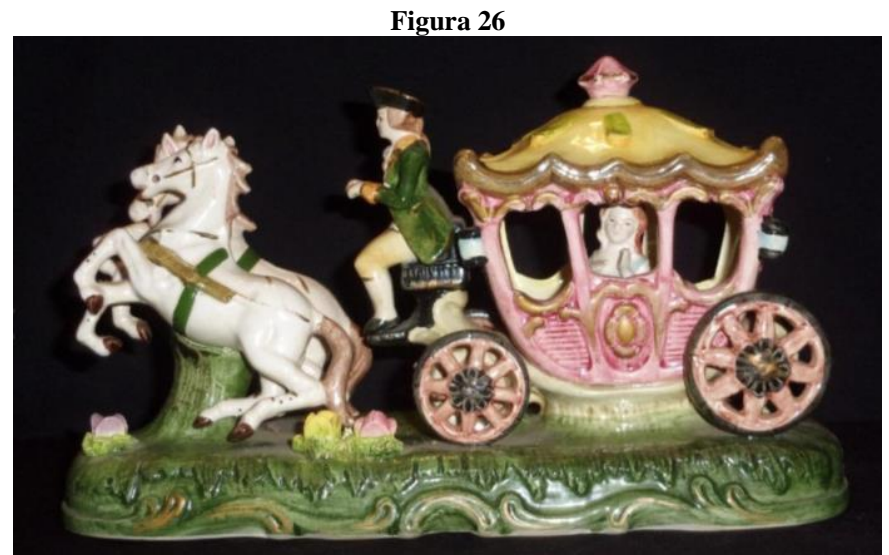

Porcelana vintage, "Cinderela", oferecida no Ebay, lance inicial US\$ 69,99. http://www.ebay.com/itm/Vintage-Porcelain-Cinderella-Carriage-with-Lady-

Horses-Coachman-Figurine-/232310529065?hash=item3616c95c29

Como se vê, as cenas de cortesia não estão isoladas. Sua sobrevivência por mais de 240 anos se deve à importância do espaço doméstico para o desenvolvimento da subjetividade, à reinserção e ressignificação constantes das cenas no circuito de produção e consumo da cultura de massa e, por fim, à nossa especial capacidade de investir nos objetos como mediadores inacabados de nossas fantasias e devaneios.

RECEBIDO EM: 01/03/2017 APROVADO EM: 10/07/2017 